\title{
Factors influencing the spatio-temporal occurrence of fish eggs and larvae in a northern, physically dynamic coastal environment*
}

\author{
Réjean Laprise**, Pierre Pepin*** \\ Department of Fisheries and Oceans, Science Branch, PO Box 5667, St. John's, Newfoundland, Canada A1C 5X1
}

\begin{abstract}
Distribution patterns, abundance and species composition of the assemblages of fish eggs and larvae in Conception Bay. Newfoundland, Canada, during the early summers of 1990 and 1991 are described. Several species appear to use Conception Bay as a spawning ground. Interannual and seasonal differences in both species composition and abundance in the bay appear to be associated with differences in environmental conditions, particularly with temperature. Both egg and larval abundances were lower by an order of magnitude in 1991 corresponding to the coldest and less saline waters. Temperature and wind were the environmental factors most associated with the spatial distribution of eggs. In both years, highest abundances of all species were usually found at the head and the eastern side of the bay, corresponding to the warmest waters under dominant westerly winds. On one occasion, greatest abundances and warmer waters were found on the western side of the bay, concomitant with a southerly wind episode. Clustering samples by their relative species composition revealed well-defined assemblages of fish larvae. The variability in relative species composition was strongly associated with the physico-chemical conditions of the surface layer and was consistent with patterns of seasonal successions observed in other ecosystems. We propose that temperature is the principal factor controlling spatio-temporal occurrence of fish eggs and larvae in Conception Bay and, most probably, in coastal waters of Newfoundland and Labrador, Canada. This association may be critical in ecosystems characterized by an extremely short growing season. Conception Bay may play an important role in the early-life history of fish inhabiting the northeast Newfoundland/Labrador shelf. Even if a smaller proportion of fish reproduced in the coastal region, their offspring may contribute significantly to the number of individuals recruiting to the population if growth and survival are considerably higher in coastal areas than in offshore areas due to the presence of more favourable habitats for early-life stages of fish.
\end{abstract}

KEY WORDS: Ichthyoplankton - Diversity · Habitat - Environmental variability - Strategy - Recruitment . Atlantic

\section{INTRODUCTION}

An essential aspect of fish reproduction is that eggs and larvae be placed in favourable habitats with characteristics that will maximise the probability of survival through the planktonic phase. In fact, there is

\footnotetext{
- Contribution to the Northern Cod Science Program

- Present address: Department of Epidemiology and Biostatistics, McGill University, Lady Meredith House, Room 306, 1110 Pine Avenue West, Montréal, Québec, Canada H3A 1 A 3

-..Addressee for reprint requests
}

a general consensus that most of the mortality of individuals in a fish population occurs during the early-life stages (Cushing 1975). Favourable habitats have been defined by both their biological (high abundance of food, low abundance of predators; Leggett 1985) and physico-chemical characteristics isuitable salinitytemperature conditions: Laprise \& Dodson 1993; circulation patterns promoting retention or transport to nursery areas: Harden Jones 1969, Sinclair 1988).

Coastal environments such as bays, fjords and islands may constitute favourable habitats for the early-life history of a great number of fish living in a variety of marine ecosystems (Frank \& Leggett 1983, 
Boehlert \& Mundy 1993, Leis 1993, McGowen 1993). These environments are often characterized by high availability of food organisms (Frank \& Leggett 1982, 1983, Taggart \& Leggett 1987, Doyle \& Ryan 1989), low abundance of larval predators (Frank \& Leggett 1982, 1983), and may be characterized by circulation features which enhance retention of planktonic stages of fish. Previous studies have demonstrated that coastal areas are commonly used as spawning and nursery areas by a variety of species that are otherwise 'ecologically' different, whether they live in various habitats as adults (e.g. pelagos, benthos and intertidal zone) or exhibit distinct spawning habits (e.g. demersal, pelagic or beach spawning) (Ellertsen et al. 1981, Frank \& Leggett 1983, Doyle \& Ryan 1989, Doyle et al. 1993, McGowen 1993).

Although coastal environments appear to be important in the life cycle of many species of fish in northern marine ecosystems, little is known about spatiotemporal patterns of utilization by different species or the factors controlling these patterns. Such studies are scant, even in the traditionally most productive ecosystems such as the Northwesi Aildulic. Documenting their utilization on different spatial and temporal scales in relation to the variability of the environment represents an essential step towards understanding and predicting the effects of environmental changes on fish populations.

In this paper, we describe the distribution patterns, abundance and species composition of the assemblages of fish eggs and larvae in Conception Bay, a northern, physically dynamic coastal environment on the northeastern shore of Newfoundland, Canada. Our objectives were (1) to determine whether the large coastal embayments in Newfoundland constitute spawning and nursery areas for fish of the northeast Newfoundland shelf as in similar ecosystems, and (2) to assess whether the spatio-temporal occurrence of eggs and larvae in the area are associated with the environmental conditions (e.g. temperature, salinity, and day of year) that are most commonly associated with spatio-temporal distribution of ichthyoplankton in coastal waters (e.g. Richardson et al. 1980, Loeb et al. 1983a, b).

Conception Bay is part of the Labrador/northeast Newfoundland shelf ecosystem. The region is characterized by an extensive shelf system constituted of shallow banks $(<200 \mathrm{~m})$ and deep channels extending to more than $360 \mathrm{~km}$ offshore and spanning more than $2000 \mathrm{~km}$ from north to south (Fig. 1). Conception Bay is a fjord approximately $50 \mathrm{~km}$ long and $25 \mathrm{~km}$ wide with a maximum depth exceeding $300 \mathrm{~m}$ and a total surface area of about $1000 \mathrm{~km}^{2}$. Previous studies of ichthyoplankton in this region have either been limited to offshore waters $>20 \mathrm{~km}$ (Frost 1938, Serebryakov 1965) or

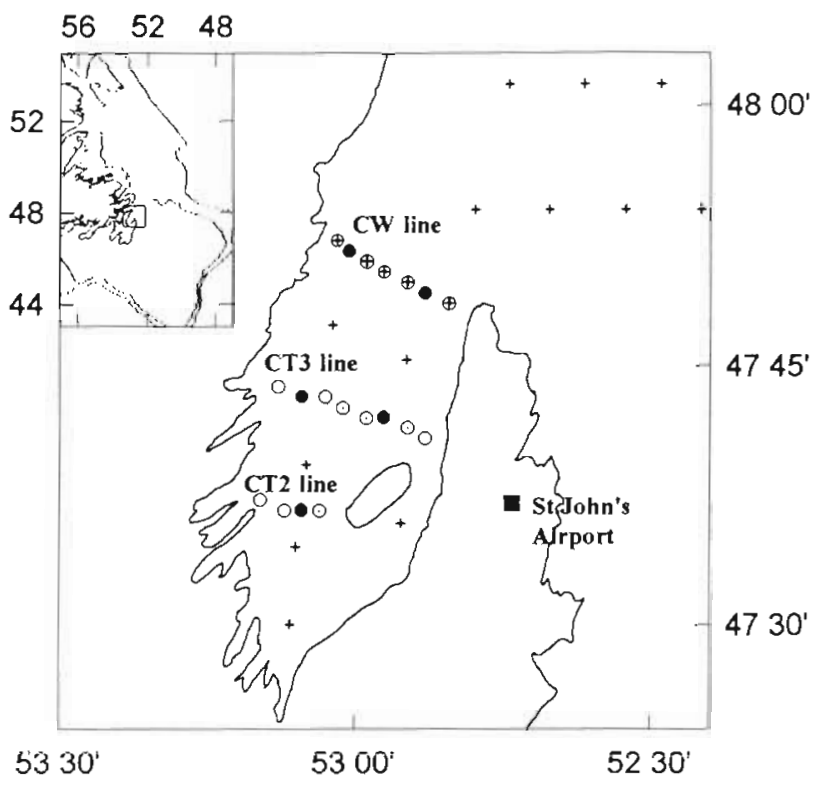

Fig. 1. Conception Bay, Newfoundland, Canada, showing stations sampled in $1990(0, \bullet)$ and $1991(+, \bullet)$ and the site of the weather station at St. John's Airport. (-) Samples used in

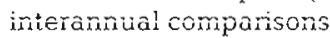

to small embayments $<1000 \mathrm{~m}$ (Frank \& Leggett 1981, 1983, Taggart \& Leggett 1987). While most commercial species of fish are believed to reproduce mainly on the shelf, the presence of eggs, larvae and juveniles inshore (Frank \& Leggett 1981, 1983, Taggart \& Leggett 1987, Keats 1990) suggests that large bays bordering the shelf may contribute to the early-life history of fishes inhabiting the area.

\section{MATERIAL AND METHODS}

Sampling procedure. In 1990, 3 main transects located between the head and the mouth of the bay were sampled June 26-29, and July 3-4 and 11-16 (Fig. 1). Each transect consisted of 4 to 8 stations, approximately $2.7 \mathrm{~km}$ apart. Depending on time and weather conditions, all stations of 1 or 2 transects were sampled on a given day. In 1991, a grid of 11 stations, approximately $9 \mathrm{~km}$ apart and distributed throughout the bay, was sampled on July 3,9 and 15 (Fig. 1). The day after (July 4, 10 and 16), samples were collected at 7 stations located on 2 transects extending from the mouth of the bay to $36 \mathrm{~km}$ offshore. Finally, a transect of 7 stations $2.7 \mathrm{~km}$ apart located at the mouth of the bay was sampled daily July 5-8 and 11-14 (Fig. 1, line CW). All samples in both years were collected during daylight (07:00 to 19:00 h).

At each station, a vertical profile of salinity and temperature was made using a Seabird 19 (1990) or Seabird 25 (1991) CTD (conductivity/temperature/depth 
meter). Ichthyoplankton was sampled using a small pelagic trawl (mouth: $2 \times 2 \mathrm{~m}$ ) fitted with a plankton net of mesh size decreasing from $1000 \mu \mathrm{m}$ at the mouth to $333 \mu \mathrm{m}$ at the cod end (length: $8 \mathrm{~m}$ ). Two General Oceanic flowmeters were placed at the mouth of the trawl to monitor the volume of water filtered. A $15 \mathrm{~min}$ oblique tow was made between the surface and $40 \mathrm{~m}$ at a speed of 2 to 3 knots. Most fish eggs and larvae in Conception Bay are found in the surface layer which does not exceed $40 \mathrm{~m}$ in depth (J. T. Anderson pers. comm., Northwest Atlantic Fisheries Center, St. John's, $\mathrm{NF}$ ). Volume of water filtered at each tow ranged between 727 and $3425 \mathrm{~m}^{3}$.

Ichthyoplankton was preserved in $2 \%$ buffered formaldehyde and later sorted by the Atlantic Reference Center (Huntsman Marine Science Center, St. Andrews, NB, Canada). Taxa that exceeded 200 eggs or larvae in a given sample were subsampled using a beaker technique (van Guelpen et al. 1982). Fish eggs and larvae were identified to the lowest taxonomic level possible and larvae were measured to the nearest $\mathrm{mm}$. In 1991, eggs were assigned one of 4 development stages according to Markle \& Frost (1985) criteria.

Numbers of eggs and larvae in each sample were standardized to $1000 \mathrm{~m}^{3}$. Abundance estimates of each taxon were corrected for unidentified individuals $(<0.5 \%)$.

Data analysis. Distribution patterns were described along 2 distinct frames of reference: a geographical framework to visualise the spatio-temporal distribution of fish eggs and larvae, and an ecological framework to assess possible associations between biological descriptors and environmental variables (Fromentin et al. 1993). Descriptions were made for 2 levels of biological organization: individual species and species assemblages.

Individual species: Temporal comparisons of abundance, size or development stage of eggs and larvae in Conception Bay were made between years (interannual) and between different periods within a cruise (ca weekly), herein referred to as seasonal comparisons. Analyses were performed using subsets of samples chosen to avoid sampling bias due to differences in aggregation of samples in space and time between sampling periods. Interannual comparisons of mean abundance and size were made using samples collected at 5 stations distributed throughout the bay on 3 occasions in both years (July 3-4, 9-12 and 14-16; Fig. 1). Seasonal comparisons in 1990 were made between 4 periods (June 27-28, July 3-4, 11-12 and 15-16) using samples collected at stations of lines CT3 and CW (Fig. 1). In 1991, seasonal comparisons were made using all stations visited on July 3,9 and 15 (Fig. 1; solid circles and crosses inland of line CW).
Spatial patterns in distribution of eggs and larvae were described by producing composite maps of abundance using all samples collected in the bay and adjacent shelf waters during a 2 or 3 d period. In addition, in 1991, statistical comparisons were made between samples collected within the bay (July 3,9 and 15) and on adjacent shelf waters (July 4, 10 and 16; Fig. 1, crosses seaward of line (W).

The associations among abundance, development stage or size and physical characteristics of the water column were assessed using multiple and partial linear correlation coefficients. Four variables were used to describe environmental conditions: surface temperature and salinity $(5 \mathrm{~m})$, and the average temperature and salinity for the top $40 \mathrm{~m}$ of the water column, which corresponds to the depth stratum sampled. Prior to analyses, linear seasonal trends were removed from biological and physical variables by calculating the residuals of a linear regression between each variable and the day of year. This was necessary because both biological and environmental variables varied as a function of time within a year, rendering it impossible to separate the effects of environmental conditions on distribution from those patterns due to seasonal trends.

Species assemblages: Multivariate analyses were carried out to determine whether there were characteristic and recurrent species assemblages of fish larvae in the bay, and to verify whether the presence of these assemblages was associated with time of year or particular environmental conditions. For these analyses, we used all samples collected in the 2 years $(\mathrm{n}=196)$. Each sample was described by 14 variables consisting in the percentage of the total abundance of larvae in a sample constituted by each of the 14 most abundant species found in the overall samples collected in the 2 years (Table 3 ). This method eliminated seasonal or yearly trends in the overall abundance of species. Whereas the abundance of all species found in the bay may vary according to oceanographic conditions or other unknown factors, the relative species composition may remain similar if all species in the assemblage show the same response to these factors. Thus, results are interpreted in terms of relative species composition without reference to seasonal or interannual differences in absolute abundances: a given species may represent $10 \%$ of the larvae collected in a sample regardless of its absolute abundance.

The 14 variables were used to construct a chisquared similarity matrix (Legendre \& Legendre 1984). The hierarchical agglomerative clustering model of Lance \& Williams (1967) was used to group the stations into homogenous clusters. Clusters were then superimposed on a projection in the reduced plane of the first 2 axes of a principal coordinate analysis in order to separate groups of samples with similar relative 
species composition. These 3 steps were done using ' $R$ ' software for Macintosh (Legendre \& Vaudor 1991). Spearman correlations were calculated between the principal axes and the original data in order to identify species that contributed the most to the formation of each group of samples (Legendre \& Legendre 1984). Finally, a discriminant analysis was conducted on the groups of species formed in order to interpret the intergroup variability in relative species composition with temperature, salinity and the day of year.

\section{RESULTS}

\section{Environmental conditions}

The water column in Conception Bay presented typical summer conditions both in 1990 (Fig. 2) and 1991. The water column was generally well stratified and characterized by a warmer, less saline and well-mixed layer of less than $23 \mathrm{~m}$ (Table 1), separated by a thermo-halocline from the very cold $\left(<2^{\circ} \mathrm{C}\right)$ and more saìine bottom iayer (Fig. 2j). At a Îew stations sampied in 1991, there was another uniform layer present within the first few meters ( $<9 \mathrm{~m}$ ) of the water column. This second uniform layer was colder and less saline than the one below. The presence of this layer was probably the result of melting from the great number of icebergs observed in the bay in 1991 but not in 1990 .

The entire water column was colder and less saline in 1991 than in 1990 (Table 1). The mean depths of the surface and upper mixed layers were greater in 1990 than in 1991, probably due to greater mixing of surface

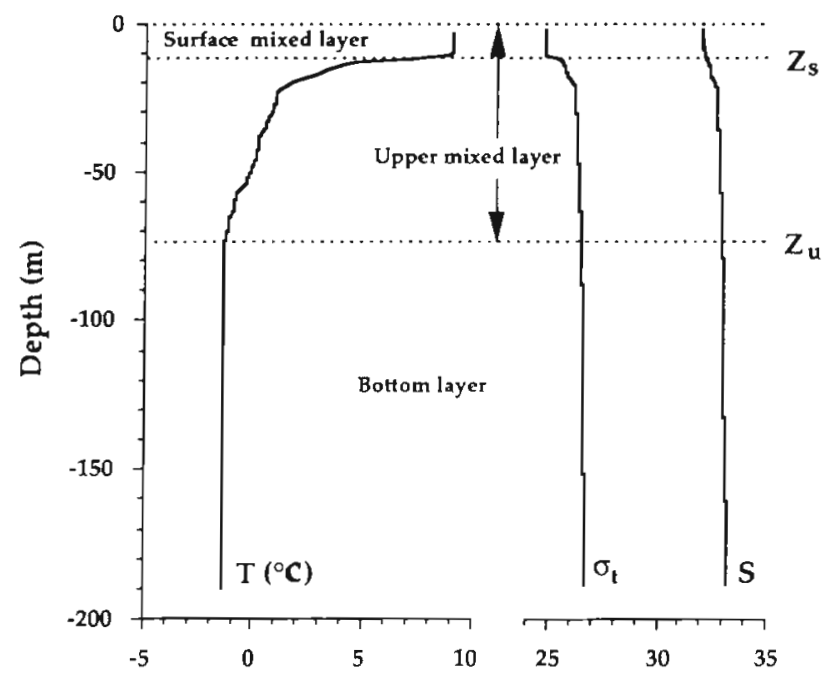

Fig. 2. Vertical profile of temperature (T), salinity (S) and density $\left(\sigma_{\tau}\right)$ at Stn CW4 (set 31) in Conception Bay, July 3 , 1990. $Z_{\mathrm{s}}$ : depth of the surface mixed layer; $Z_{4}$ : depth of the upper mixed layer
Table 1 Environmental conditions at 5 selected stations in Conception Bay (Fig. 1), 1990 and 1991. SML: surface mixed layer, defined as the depth where temperature was $1^{\circ}$ Iess than that of surface waters; UML: upper mixed layer, defined as the depth where temperature reached $-1.3^{\circ} \mathrm{C}$. including the thermocline. For wind data, overall averages were based on daily average wind speed

\begin{tabular}{|c|c|c|c|c|}
\hline Variable & Mean & $\mathrm{SD}$ & Min & $\operatorname{Max}$ \\
\hline \multicolumn{5}{|l|}{1990} \\
\hline \multicolumn{5}{|l|}{ Temperature $\left({ }^{\circ} \mathrm{C}\right)$} \\
\hline $5 \mathrm{~m}$ & 8.86 & 1.15 & 3.05 & 10.69 \\
\hline Avg. $40 \mathrm{~m}$ & 4.69 & 1.03 & 1.37 & 7.04 \\
\hline \multicolumn{5}{|l|}{ Salinity } \\
\hline $5 \mathrm{~m}^{2}$ & 31.95 & 0.11 & 31.57 & 32.65 \\
\hline Avg. $40 \mathrm{~m}$ & 32.21 & 0.10 & 32.05 & 32.74 \\
\hline \multicolumn{5}{|l|}{ Depth $(\mathrm{m})$} \\
\hline SML & 13.1 & 3.3 & 3.0 & 22.5 \\
\hline UML & 84.6 & 12.0 & 52.0 & 151.0 \\
\hline \multicolumn{5}{|l|}{ Stratification } \\
\hline Tenuperalure $\left({ }^{n} \mathrm{C}^{-1}\right)$ & 0.15 & 0.03 & 0.06 & 0.25 \\
\hline Salinity $\left(\mathrm{m}^{-1}\right)$ & 0.02 & 0.004 & 0.01 & 0.05 \\
\hline Wind speed $\left(\mathrm{m} \mathrm{s}^{-1}\right)$ & 6.1 & 2.1 & 1.25 & 9.12 \\
\hline \multicolumn{5}{|l|}{1991} \\
\hline \multicolumn{5}{|l|}{ Temperature ( $^{\circ} \mathrm{C}$ ? } \\
\hline $5 \mathrm{~m}$ & 7.31 & 1.49 & 3.84 & 10.65 \\
\hline Avg. $40 \mathrm{~m}$ & 2.23 & 0.53 & 0.21 & 3.74 \\
\hline \multicolumn{5}{|l|}{ Salinity } \\
\hline $5 \mathrm{~m}$ & 30.32 & 0.50 & 29.15 & 31.29 \\
\hline Avg. $40 \mathrm{~m}$ & 31.55 & 0.16 & 30.97 & 31.98 \\
\hline \multicolumn{5}{|l|}{ Depth $(\mathrm{m})$} \\
\hline SML & 9.8 & 1.7 & 3.5 & 16.5 \\
\hline UML & 66.3 & 7.8 & 41.0 & 83.0 \\
\hline \multicolumn{5}{|l|}{ Stratification } \\
\hline Temperature $\left({ }^{\circ} \mathrm{C} \mathrm{m}^{-1}\right)$ & 0.16 & 0.03 & 0.10 & 0.26 \\
\hline Salinity $\left(\mathrm{m}^{-1}\right)$ & 0.05 & 0.010 & 0.02 & 0.10 \\
\hline Wind speed $\left(\mathrm{m} \mathrm{s}^{-1}\right)$ & 3.7 & 1.5 & 1.6 & 6.1 \\
\hline
\end{tabular}

waters caused by the presence of wind of higher velocities in 1990, as well as higher average atmospheric temperature. Average vertical stratification of the upper mixed layer was not different for temperature between the 2 years whereas stratification in salinity was twice as much in 1991 as in 1990.

Wind appears to have a major effect on the spatial distribution of surface isotherms in the bay (Fig. 3). During most of the sampling periods in 1990 and 1991 . wind blew mainly from a westerly direction, displacing warm surface waters towards the southeastern side of the bay. This movement of surface waters induced upwelling of cold water along the west coast, creating a lateral gradient in temperature across the bay. As a result, temperature of the surface well-mixed layer was higher at the head and on the eastern side of the bay. A particularly strong lateral gradient in temperature was observed on July 11-13, 1990, concomitant with a period of higher wind velocity. On this occasion, there was a difference of more than $3.0^{\circ} \mathrm{C}$ over only 
03/04 July 1990

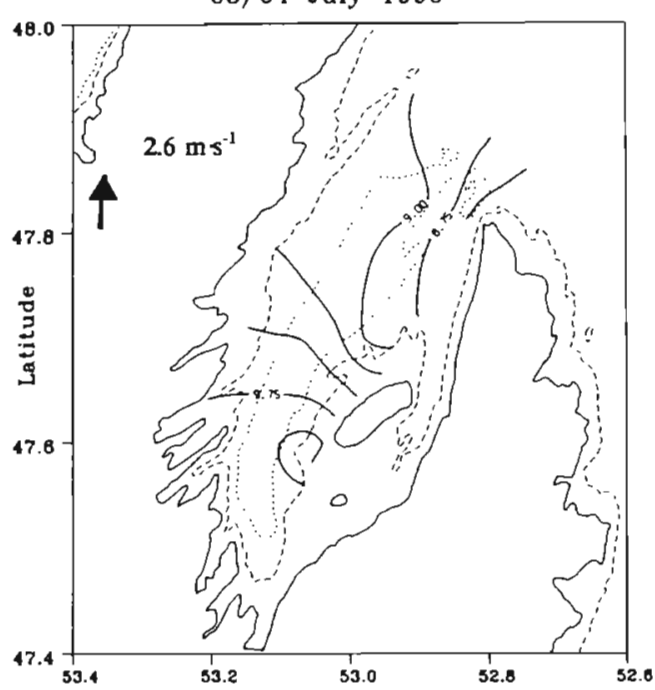

$11 / 13$ July 1990

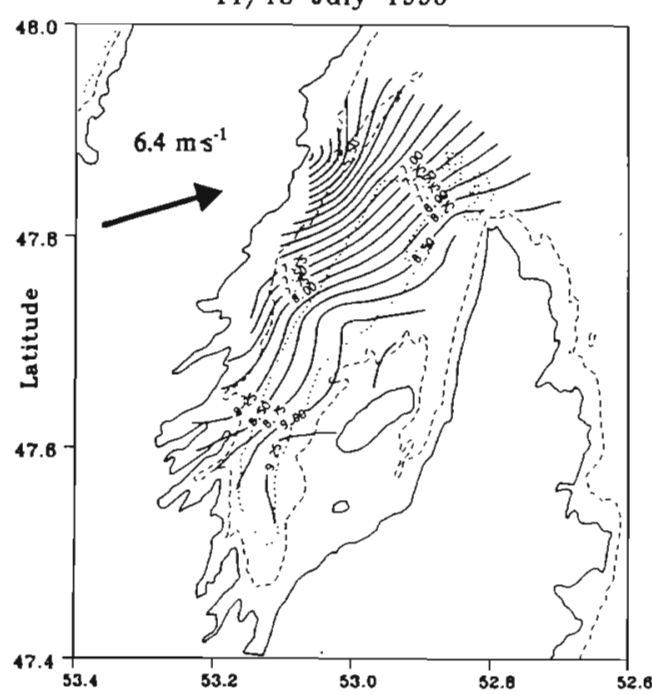

$15 / 16$ July 1990

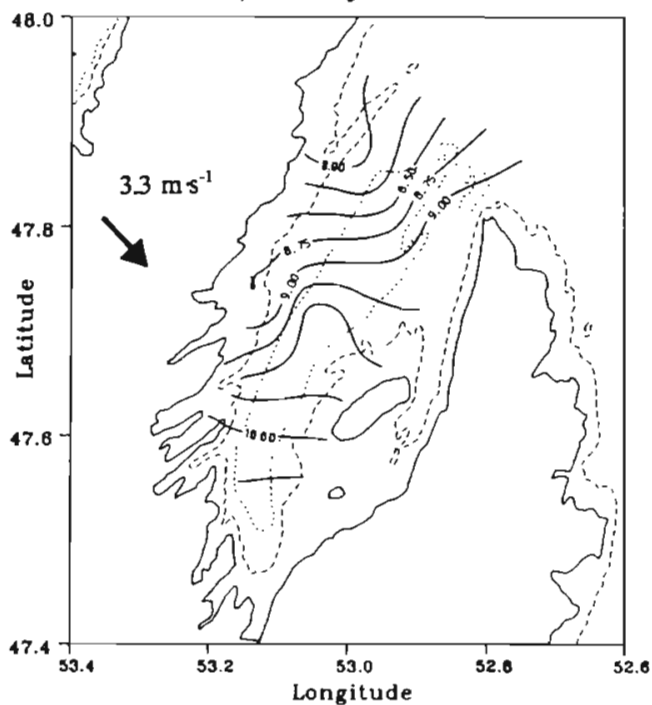

03/04 July 1991

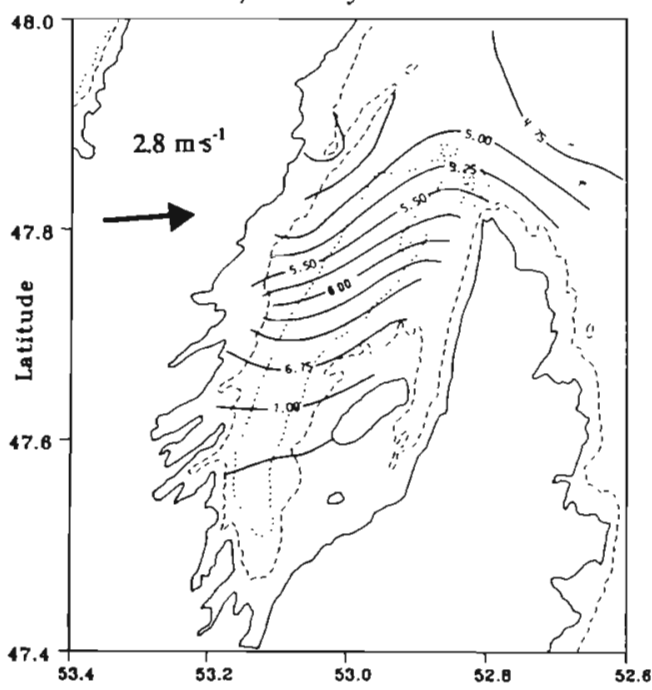

$09 / 10$ July 1991

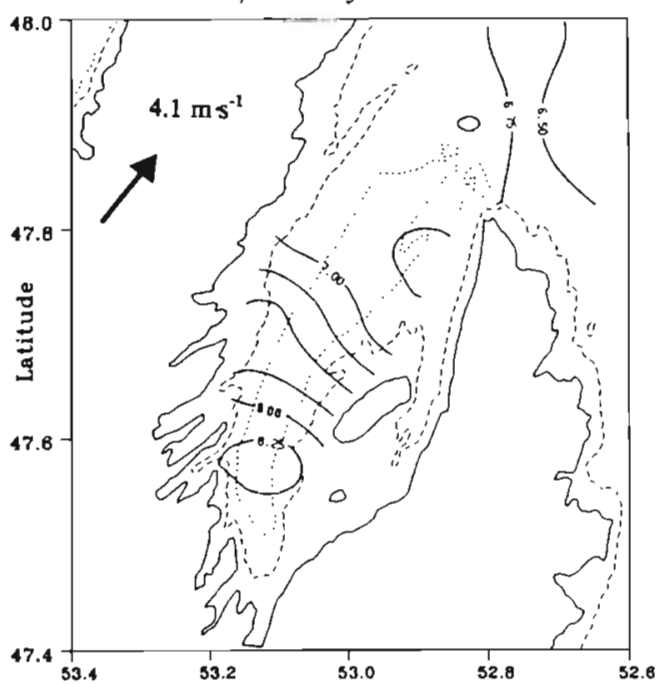

$15 / 16$ July 1991

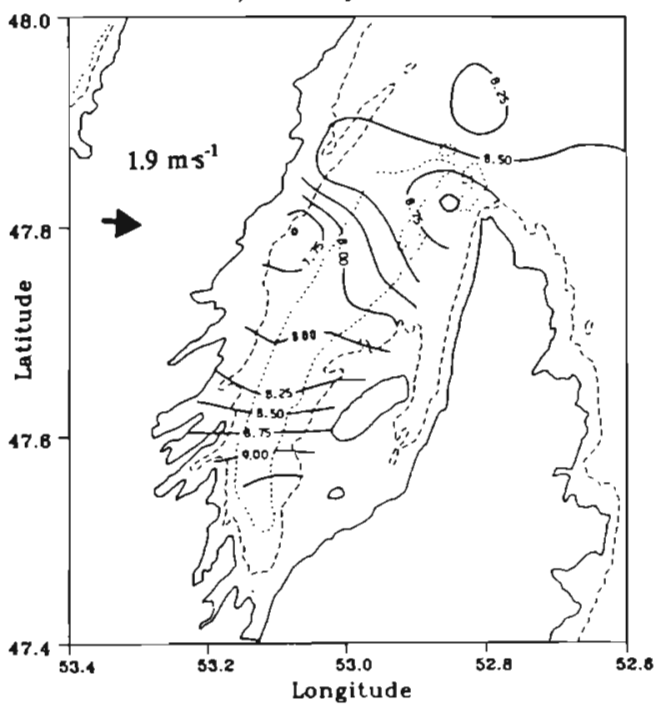

Fig. 3. Surface temperature $(5 \mathrm{~m})$ in Conception Bay, 1990 and 1991. Arrows indicate average wind speed and direction 
$15 \mathrm{~km}$ at the mouth of the bay (Fig. 3). On July 3 to 4 , 1990, wind blew mainly from the southern direction. In a manner consistent with earlier observations by Frank \& Leggett (1982), surface waters were then colder on the eastern side of the bay and warmer on the western side. Temperature and wind patterns on June 27 and 28, 1990 (not presented in Fig. 3), were similar to those observed on July 11 to 13 .

In both years, the surface layer became significantly warmer as the season progressed (Table 2) and this warming progressed from the head towards the mouth of the bay (Fig. 3). However, temperatures observed in the bay at the end of June 1990 were not reached before the middle of July in 1991. In 1990, average temperatures of the surface mixed layer increased from $7.6^{\circ} \mathrm{C}$ on June $27-28$ to $9.0^{\circ} \mathrm{C}$ on July $3-4$. On July 11-13, average surface temperatures were lower by more than $1^{\circ}$ compared to July $3-4$, probably due to the strong upwellings observed on the western side of the bay. After this event, surface waters warmed again to reach average temperatures of $8.7^{\circ} \mathrm{C}$ on July $15-16$. In 1991, surface temperatures went from an average of $\hat{0} .2^{\circ} \mathrm{C}$ on juiy $3-4$ to $8.4^{\circ} \mathrm{C}$ on July $15-16$. Sainity oí surface waters also increased significantly as the season progressed in 1990, but not in 1991 (Table 2).

Surface salinity and temperature were significantly intercorrelated when the effect of seasonal warming was removed (Table 2). However, the relationship was different between the 2 years. In 1990, stations with higher surface temperatures were on average less saline than those with lower surface temperatures. In contrast, higher surface temperatures were associated with more saline waters in 1991. Small linear correlations indicate a high variability around these patterns. Factors such as wind velocity, the presence of cloud/rain or melting iceberg may all have contributed to this variability. Temperature showed the most consistent patterns in both space and time in the 2 years sampled.

\section{Individual species distribution}

\section{Eggs}

The eggs of 8 species representing 4 families were found in Conception Bay (Table 3). The eggs of all 8 species were found in both years except witch flounder which only occurred in 1990. There was an average of $707 \pm 416$ (SD) eggs per $1000 \mathrm{~m}^{3}$ in 1990 and 4 species constituted more than $89 \%$ of all eggs sampled (Table 3). Cod and yellowtail flounder were most abundant, with more than 200 eggs per $1000 \mathrm{~m}^{3}$ on average. Plaice and cunner were next with about 100 eggs per $1000 \mathrm{~m}^{3}$.

The abundance of fish eggs in 1991 was lower by almost an order of magnitude compared to 1990 . On average, only $91 \pm 90$ fish eggs per $1000 \mathrm{~m}^{3}$ were sampled in the bay that year. All species were significantly less abundant in 1991 than in 1990 (Table 3). Cod, plaice and yellowtail constituted nearly $99 \%$ of all the eggs, with more than 19 eggs per $1000 \mathrm{~m}^{3}$. Pre-embryonic eggs (stage I), which do not last longer than a few days at the temperature observed (Page \& Frank 1989), constituted a significant proportion of all species of eggs collected (Fig. 4), indicating spawning within the bay.

Day of sampling was an important source of variability in fish egg abundance. In 1990, the mean abundance of eggs in the bay almost doubled as the season progressed, going from 467 eggs per $1000 \mathrm{~m}^{3}$ on June 27-28 to 867 eggs per $1000 \mathrm{~m}^{3}$ on July 15-16. Cod, pollock, cunner and mackerel all contributed to this increase and the last 2 species appeared in the samples only at the end of the sampling period (Fig. 5). There were also significant temporal changes in the abundance of witch flounder. However, these changes were not linear, consisting of successive increases and decreases.

In contrast to 1990, the average abundance of fish eggs in 1991 significantly decreased during the sampling period, going from an average of 144 eggs per $1000 \mathrm{~m}^{3}$ on July 3 to 75 eggs per $1000 \mathrm{~m}^{3}$ on July 15. Most of this reduction was due to plaice (Fig. 5). As in 1990, cunner and mackerel eggs appeared in the samples only at the end of the sampling period, but a week later than in 1990. No significant 
Table 3. Ichthyoplankton of Conception Bay, 1990 and 1991. Percentage of occurrence (\%O), range and mean abundance (no. $1000 \mathrm{~m}^{-3}$ ) of fish eggs (E) and larvae (L). Abundances corrected for unidentified individuals. "Average abundances significantly different between the 2 years at $p=0.05$ (2-tailed $t$-test on log-transformed data)

\begin{tabular}{|c|c|c|c|c|c|c|c|c|}
\hline \multirow[t]{2}{*}{ Species } & \multirow{2}{*}{\multicolumn{2}{|c|}{ Common name }} & \multicolumn{3}{|c|}{$\longrightarrow 1990$} & \multicolumn{3}{|c|}{1991} \\
\hline & & & $\% \mathrm{O}^{\mathrm{a}}$ & Range $^{\pi}$ & Mean $(S D)^{b}$ & $\% \mathrm{O}^{r}$ & Range $^{c}$ & Mean $(\mathrm{SD})^{d}$ \\
\hline \multicolumn{9}{|l|}{ Agonidae } \\
\hline Agonus decagonus & Atlantic poacher & $\mathrm{L}$ & 8 & $0-1$ & $0.09(0.33)$ & - 49 & $0-16$ & $0.77(1.09)$ \\
\hline Aspidophoroides monopterygius & Alligatorfish & $\mathrm{L}$ & 27 & $0-2$ & $0.06(0.16)$ & 21 & $0-3$ & $0.43(0.79)$ \\
\hline Aspidophoroides olriki & Arctic alligatorfish & $\mathrm{L}$ & 0 & 0 & 0 & 1 & $0-<1$ & 0 \\
\hline \multicolumn{9}{|l|}{ Ammodytidae } \\
\hline Ammodytes sp. & Sand lance & $\mathrm{L}$ & 6 & $0-1$ & $0.07(0.17)$ & 24 & $0-2$ & $0.15(0.43)$ \\
\hline \multicolumn{9}{|l|}{ Clupeidae } \\
\hline Clupea harengus & Atlantic herring & L & 44 & $0-5$ & $1.21(1.59)$ & - & $0-<1$ & 0 \\
\hline \multicolumn{9}{|l|}{ Cottidae } \\
\hline Gymnocanthus tricuspis & Arctic staghorn sculpin & L & 1 & $0-<1$ & 0 & 2 & $0-<1$ & $0.05(0.19)$ \\
\hline Icelus sp. & & $\mathrm{L}$ & 0 & 0 & 0 & 6 & $0-1$ & $0.12(0.36)$ \\
\hline Myoxocephalus octodecemspinosus & Longhorn sculpin & $\mathrm{L}$ & 3 & $0-<1$ & 0 & 1 & $0-<1$ & 0 \\
\hline Myoxocephalus scorpius & Shorthorn sculpin & $\mathrm{L}$ & 0 & 0 & 0 & - 24 & $0-3$ & $0.18(0.33)$ \\
\hline Triglops sp. & & $\mathrm{L}$ & 0 & 0 & 0 & 1 & $0-<1$ & 0 \\
\hline \multicolumn{9}{|l|}{ Cyclopteridae } \\
\hline Cyclopterus lumpus & Lumpfish & $\mathrm{L}$ & 0 & 0 & 0 & 1 & $0-<1$ & $0.05(0.18)$ \\
\hline Liparis atlanticus & Atlantic snailfish & $\mathrm{L}$ & 94 & $0-23$ & $5.21(3.03)$ & * 24 & $0-18$ & $0.51(0.83)$ \\
\hline Liparis fabricii & Gelatinous snailfish & $\mathrm{L}$ & 0 & 0 & 0 & 2 & $0-<1$ & 0 \\
\hline Liparis gibbus & Dusky snailfish & L & 33 & $0-2$ & $0.22(0.38)$ & * 87 & $0-28$ & $6.56(7.91)$ \\
\hline Liparis inquilinus & Inquiline snailfish & L & 1 & & 0 & 0 & $0-<1$ & 0 \\
\hline Paraliparis sp. & & I & 0 & & 0 & 1 & $0-1$ & 0 \\
\hline \multicolumn{9}{|l|}{ Gadidae } \\
\hline Boreogadus saida & Arctic cod & L & 0 & 0 & 0 & * 80 & $0-11$ & $2.39(1.70)$ \\
\hline Enchelyopus cimbrius & Fourbeard rockling & $E$ & 23 & $0-28$ & $3.11(7.31)$ & 15 & $0-4$ & $0.21(0.60)$ \\
\hline \multirow[t]{2}{*}{ Gadus morhua } & Atlantic cod & $E$ & 93 & $0-1022$ & $217.92(216.90)$ & $\cdot 100$ & $1-213$ & $35.17(37.34)$ \\
\hline & & $\mathrm{L}$ & 99 & $0-11$ & $3.70(2.35)$ & * 33 & $0-5$ & $0.62(1.28)$ \\
\hline \multirow[t]{2}{*}{ Pollachius virens } & Pollock & $E$ & 58 & $0-53$ & $6.34(7.24)$ & - 21 & $0-9$ & $0.25(0.61)$ \\
\hline & & L & 16 & $0-<1$ & $0.14(0.27)$ & 0 & 0 & 0 \\
\hline \multicolumn{9}{|l|}{ Labridae } \\
\hline \multirow[t]{2}{*}{ Tautogalabrus adspersus } & Cunner & $E$ & 50 & $0-1774$ & $93.26(151.96)$ & 4 & $0-40$ & $0.37(1.12)$ \\
\hline & & $\mathrm{L}$ & 12 & $0-4$ & $0.30(0.85)$ & 0 & 0 & 0 \\
\hline \multicolumn{9}{|l|}{ Osmeridae } \\
\hline Mallotus villosus & Capelin & $\mathrm{L}$ & 78 & $0-986$ & $158.82(147.30)$ & 0 & 0 & 0 \\
\hline Pleuronectidae & & & & & & & & \\
\hline Glyptocephalus cynoglossus & Witch flounder & $E$ & 40 & $0-439$ & $47.30(65.57)$ & 0 & 0 & 0 \\
\hline & & $\bar{L}$ & 15 & $0-2$ & $0.07(0.16)$ & 0 & 0 & 0 \\
\hline Hippoglossoides platessoides & American plaice & $E$ & 100 & $8-365$ & $107.60(60.65)$ & - 99 & $0-200$ & $35.86(48.90)$ \\
\hline & & $\bar{L}$ & 100 & $2-231$ & $46.82(23.75)$ & * 63 & $0-15$ & $2.36(2.73)$ \\
\hline Liopsetta putnami & Smooth flounder & L & 1 & $0-<1$ & 0 & 0 & 0 & 0 \\
\hline Pleuronectes americanus & Winter flounder & $\mathrm{L}$ & 76 & $0-25$ & $3.46(2.65)$ & 5 & $0-3$ & $0.09(0.34)$ \\
\hline Pleuronectes ferrugina & Yellowtail flounder & $E$ & 99 & $0-1716$ & $204.66(126.64)$ & * 67 & $0-548$ & $19.23(26.23)$ \\
\hline & & $\mathrm{L}$ & 61 & $0-110$ & $14.81(19.00)$ & 1 & $0-1$ & 0 \\
\hline Pholidae & & & & & & & & \\
\hline Pholis gunnellus & Rock gunnel & L & 3 & $0-<1$ & 0 & 22 & $0-4$ & 0 \\
\hline Scombridae & & & & & & & & \\
\hline Scomber scombrus & Atlantic mackerel & $E$ & 51 & $0-868$ & $26.88(63.47)$ & & $0-2$ & $0.3(0.13)$ \\
\hline & & $L$ & 12 & $0-2$ & $0.04(0.12)$ & 0 & 0 & 0 \\
\hline Scorpaenidae & & & & & & & & \\
\hline Sebastes sp. & Redfish & $L$ & 63 & $0-14$ & $0.57(0.74)$ & 37 & $0-4$ & $0.24(0.49)$ \\
\hline Stichaeidae & & & & & & & & \\
\hline Lumpenus sp. & & $\mathrm{L}$ & 5 & $0-<1$ & 0 & - 88 & $0-33$ & $3.61(3.92)$ \\
\hline Stichaeus punctatus & Arctic shanny & $\mathrm{L}$ & 35 & $0-35$ & $2.59(8.92)$ & . 78 & $0-24$ & $2.59(2.38)$ \\
\hline Ulvaria subbiffurcata & Radiated shanny & $\mathrm{L}$ & 99 & $0-462$ & $38.66(40.62)$ & * 72 & $0-82$ & $5.37(7.33)$ \\
\hline "Calculated using 97 samples coll & cted in the bay betwe & & $28 a$ & ly 16 , & & & & \\
\hline${ }^{\mathrm{b}}$ Calculated using the abundance & t 5 stations on July 3 & & 2 , an & $-16(N$ & & & & \\
\hline 'Calculated using 82 samples colle & cted in the bay from $\mathrm{Ju}$ & 3 & 6,199 & & & & & \\
\hline${ }^{\mathrm{C}}$ Calculated using the abundance a & it 5 stations on July 3,9 & & $15(\mathrm{~N}$ & & & & & \\
\hline
\end{tabular}




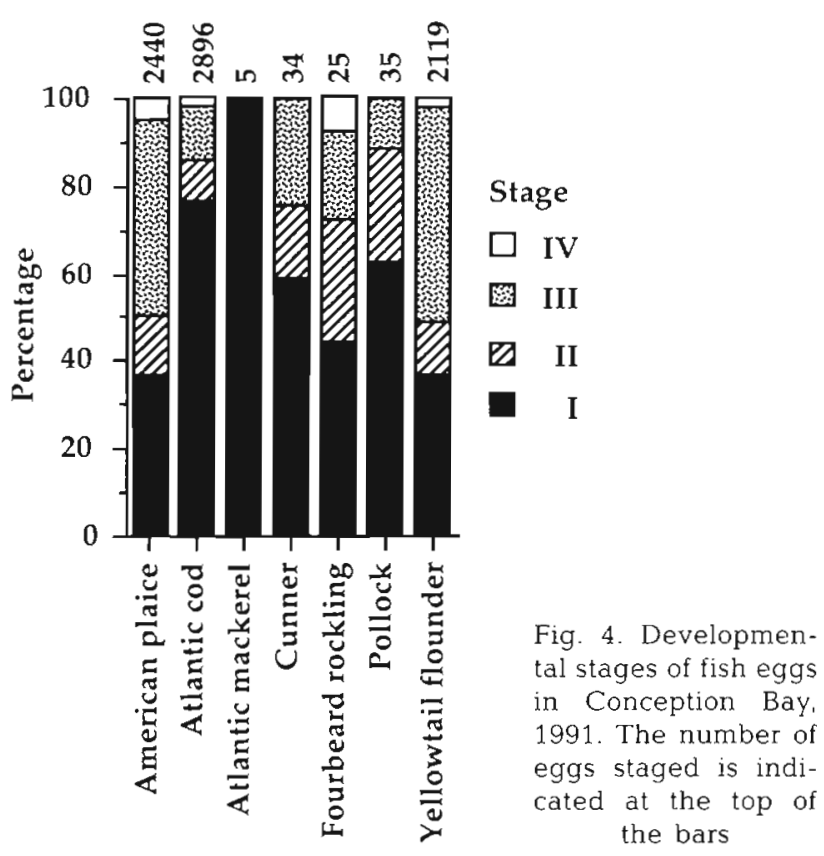

relationship was found between eg̣ development stage and day of year, suggesting continuous spawning activity during the whole period sampled.

Under dominant westerly winds, greatest abundances of all species were generally observed at the head and on the eastern side of the bay in both years, forming a skewed distribution as in the case of surface temperature (Figs. $3 \& 6$ ). Moreover, as for temperature, an exception occurred on July $3-4,1990$, when eggs were more abundant in the northwestern part of the bay. This was concomitant with the southerly wind episode observed during that period and indicates that, as for temperature, the spatial distribution of eggs in the bay is influenced by changes in wind patterns. The distribution of eggs on June 27-28, 1990 (not presented in Fig. 6), was similar to other observations made under westerly wind conditions. In 1991, fish eggs were always more abundant in the bay than in adjacent shelf waters where only 3 species were found (cod, plaice and yellowtail). In the case of these species, eggs were less abundant on the shelf than in the bay (Mann-Whitney test, $p<0.05$ ), and yellowtail was found on the shelf only on July 10.

Salinity and temperature together explained $27 \%$ and $52 \%$ of the variability in total abundance in 1990 and 1991, respectively (Table 4). In the case of the most abundant species within each year, temperature and salinity significantly explained between 11 and 52\% of the variability. In 1990, highest abundances of all species were associated with the warmest and less saline waters. In 1991, fish eggs of all species were also associated with the warmest waters but with the most saline waters. This suggests that temperature was the
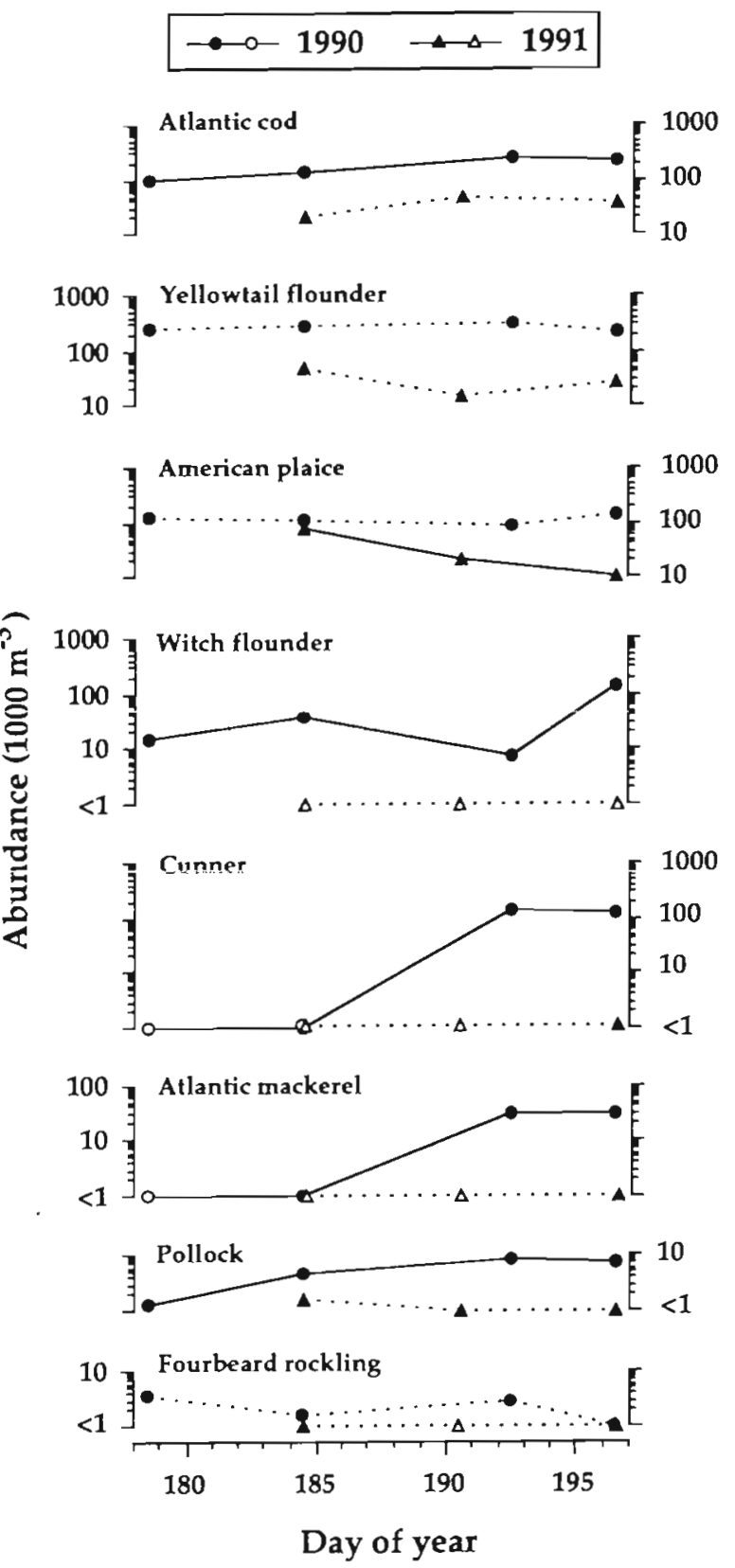

Fig. 5. Seasonal fluctuations in the abundance of fish eggs in Conception Bay, 1990 and 1991. Open symbols indicate absence of the species in the samples. Solid lines indicate significant differences $(p<0.05)$ between 2 adjacent sampling periods (1-way ANOVA and SNK tests on Iog-transformed data)

most important factor explaining the distribution of eggs. While the relationship with temperature did not change between the 2 years, the association with salinity was reversed and reflected interannual differences in the relationship between temperature and salinity (Table 2). In 1991, later stages of development of both plaice and yellowtail were also associated with higher temperatures (Table 5). 

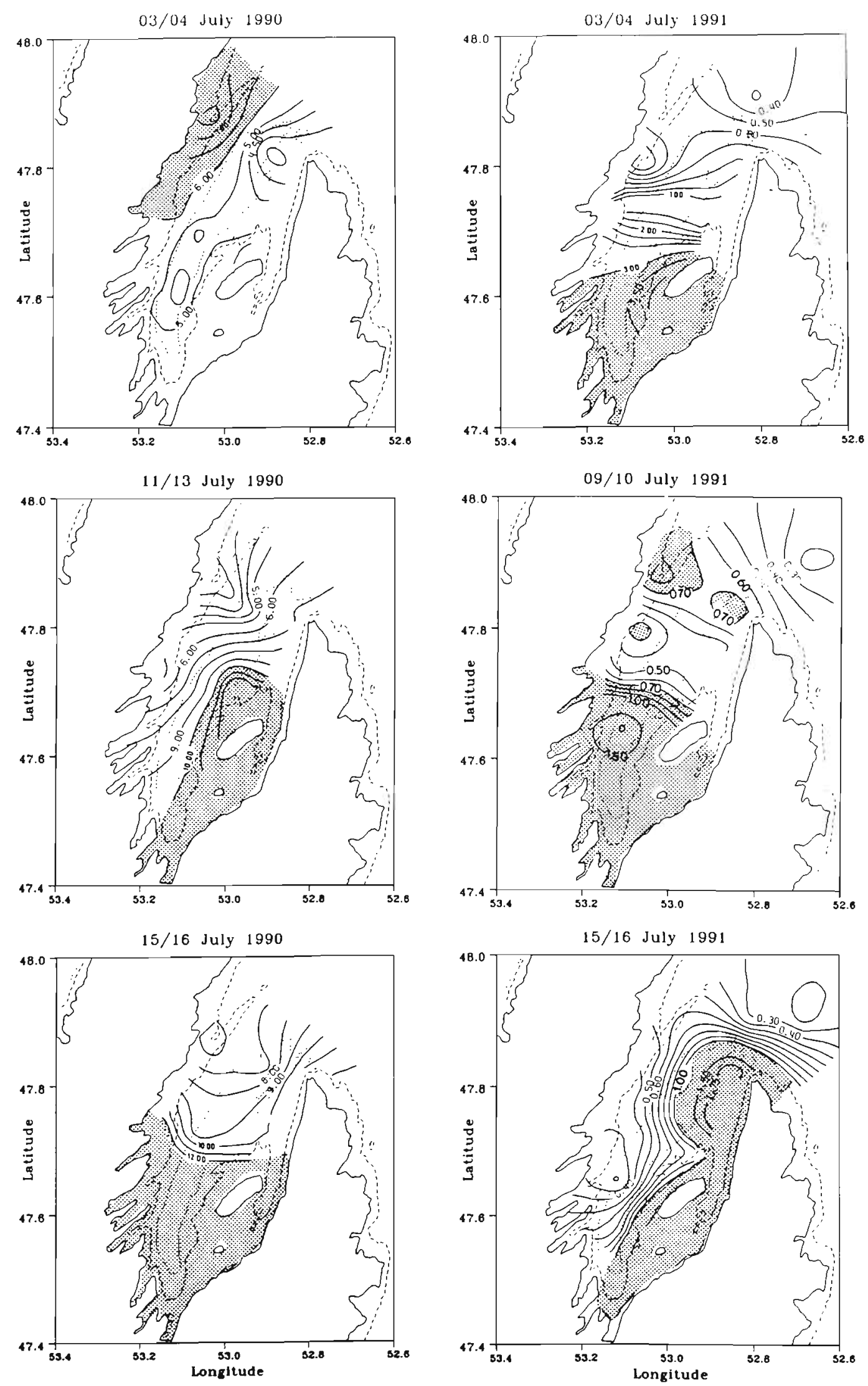

Fig. 6. Spatial distribution of fish eggs in Conception Bay, 1990 and 1991. Abundances in number per $10 \mathrm{~m}^{3}$. Shaded areas indicate regions of higher abundances 
Table 4. Relationships between log-transformed abundances of fish eggs and environmental conditions in Conception Bay, 1990 and 1991. Linear correlation coefficients were partialled for the day of year. Squared multiple correlation coefficients $\left(\mathrm{R}^{2}\right)$ are also presented. Only significant $(p<0.05)$ coefficients are shown. The sign of non-significant correlations is also shown

\begin{tabular}{|c|c|c|c|c|c|}
\hline \multirow{2}{*}{$\begin{array}{l}\text { Year } \\
\text { Species }\end{array}$} & \multicolumn{2}{|c|}{ Temperature } & \multicolumn{2}{|c|}{ Salinity } & \multirow[t]{2}{*}{$R^{2}$} \\
\hline & $5 \mathrm{~m}$ & Avg. $40 \mathrm{~m}$ & $5 \mathrm{~m}$ & Avg $40 \mathrm{~m}$ & \\
\hline \multicolumn{6}{|l|}{$1990(\mathrm{n}=97)$} \\
\hline American plaice & 0.31 & 0.36 & -0.22 & -0.30 & 0.18 \\
\hline Atlantic cod & 0.23 & 0.30 & - & -0.27 & 0.11 \\
\hline Atlantic mackerel & 0.40 & + & -0.41 & - & 0.25 \\
\hline Cunner & + & + & -0.38 & - & 0.17 \\
\hline Pollock & + & + & -0.28 & - & 0.12 \\
\hline All species & 0.46 & 0.31 & -0.34 & -0.24 & 0.27 \\
\hline \multicolumn{6}{|l|}{$1991(\mathrm{n}=98)$} \\
\hline American plaice & 0.57 & 0.27 & 0.54 & 0.31 & 0.46 \\
\hline Atlantic cod & 0.59 & 0.44 & 0.47 & 0.25 & 0.45 \\
\hline Fourbeard rockling & 0.34 & 0.21 & + & + & 0.11 \\
\hline Pollock & 0.25 & 0.30 & + & + & 0.11 \\
\hline Yellowtail flounder & 0.62 & 0.45 & 0.53 & 0.29 & 0.52 \\
\hline All species & 0.63 & 0.42 & 0.53 & 0.27 & 0.52 \\
\hline
\end{tabular}

$\mathrm{m}^{3}$ (Table 3). Plaice, radiated shanny and yellowtail were next with mean abundances ranging from 15 to 47 larvae per $1000 \mathrm{~m}^{3}$. These 4 species constituted nearly $97 \%$ of all fish larvae captured.

As in the case of eggs, total abundance of fish larvae was lower by an order of magnitude in 1991. The average catch was $28 \pm 18$ larvae per $1000 \mathrm{~m}^{3}$. The assemblage of species was more diversified than in 1990 - Shannon-Wiener index: $H^{\prime}=$ $2.1(1990)$ and $3.2(1991)$ - and the 4 most abundant species only constituted $70 \%$ of all captures. The most abundant species were, in decreasing order, radiated shanny, dusky snailfish, Lumpenus sp., Arctic shanny and plaice, the only species to exceed 1 larvae per $1000 \mathrm{~m}^{3}$ (Table 3).

Most abundant species captured in 1990 (13 species) were mainly newly hatched individuals (Fig. 7). Exceptions were Agonidae, herring, sand lance, rock gümel, Lumpenus sp. and Archic shōnny.

Larvae

The species of fish larvae found in Conception Bay in the 2 years were different. At least 32 species (6 genera could not be identified to species) belonging to 13 families were identified (Table 3 ). A total of 24 species/genera were found in 1990, 26 species/genera were collected in 1991, and only 18 species/genera were common to both years. Fish species with demersal eggs dominated the larval assemblages, comprising 64 and $79 \%$ of the species present in 1990 and 1991. Differences in taxonomic composition were mainly due to rare specimens collected in only a few catches in 1 year such as the inquiline snailfish in 1990 and the Arctic alligatorfish in 1991 (Table 3). In addition, some species were absent in 1991, most probably due to delayed biological development: whereas pollock, cunner and mackerel larvae were not captured in 1991, eggs of these species were nonetheless found in the bay that year. Finally, some species that were common and abundant in one year, such as witch flounder and capelin in 1990 and Arctic cod and shorthorn sculpin in 1991, were not found in the bay the other year

The average catch in 1990 was $238 \pm 177$ larvae per $1000 \mathrm{~m}^{3}$ Capelin was by far the most abundant species with average abundances of more than 150 larvae per 1000
Table 5. Relationships between the average development stage of eggs or length of larvae and environmental conditions in Conception Bay, 1990 and 1991. Linear correlation coefficients were partialled for the day of year. Only samples containing more than 5 eggs or larvae were used in the calculations. Number of samples given in parentheses. Squared multiple correlation coefficients $\left(R^{2}\right)$ are also presented. Only significant $(p<0.05)$ coefficients are shown. The sign of non-significant correlations is also shown

\begin{tabular}{|c|c|c|c|c|c|}
\hline \multirow{3}{*}{$\begin{array}{l}\text { Year } \\
\text { Species }\end{array}$} & \multicolumn{2}{|c|}{$\begin{array}{l}\text { Temperature } \\
5 \mathrm{~m} \mathrm{Avg.} 40 \mathrm{~m}\end{array}$} & \multicolumn{2}{|c|}{$\begin{array}{c}\text { Salinity } \\
5 \mathrm{~m} \text { Avg. } 40 \mathrm{~m}\end{array}$} & $\mathrm{R}^{2}$ \\
\hline & & & & & \\
\hline & & & & & \\
\hline American plaice (79) & 0.45 & 0.29 & 0.34 & + & 0.24 \\
\hline Yellowtail flounder (52) & 0.41 & + & 0.26 & 0.29 & 0.33 \\
\hline \multicolumn{6}{|l|}{ Larvae } \\
\hline \multicolumn{6}{|l|}{1990} \\
\hline Atlantic cod (64) & + & - & 0.42 & 0.24 & 0.26 \\
\hline Capelin (52) & 0.29 & + & -0.45 & -0.36 & 0.22 \\
\hline Radiated shanny (84) & 0.36 & 0.26 & -0.24 & - & 0.15 \\
\hline \multicolumn{6}{|l|}{1991} \\
\hline Arctic shanny (34) & 0.50 & + & 0.47 & + & 0.31 \\
\hline Dusky snailfish (50) & -0.40 & - & -0.30 & -0.29 & 0.21 \\
\hline
\end{tabular}




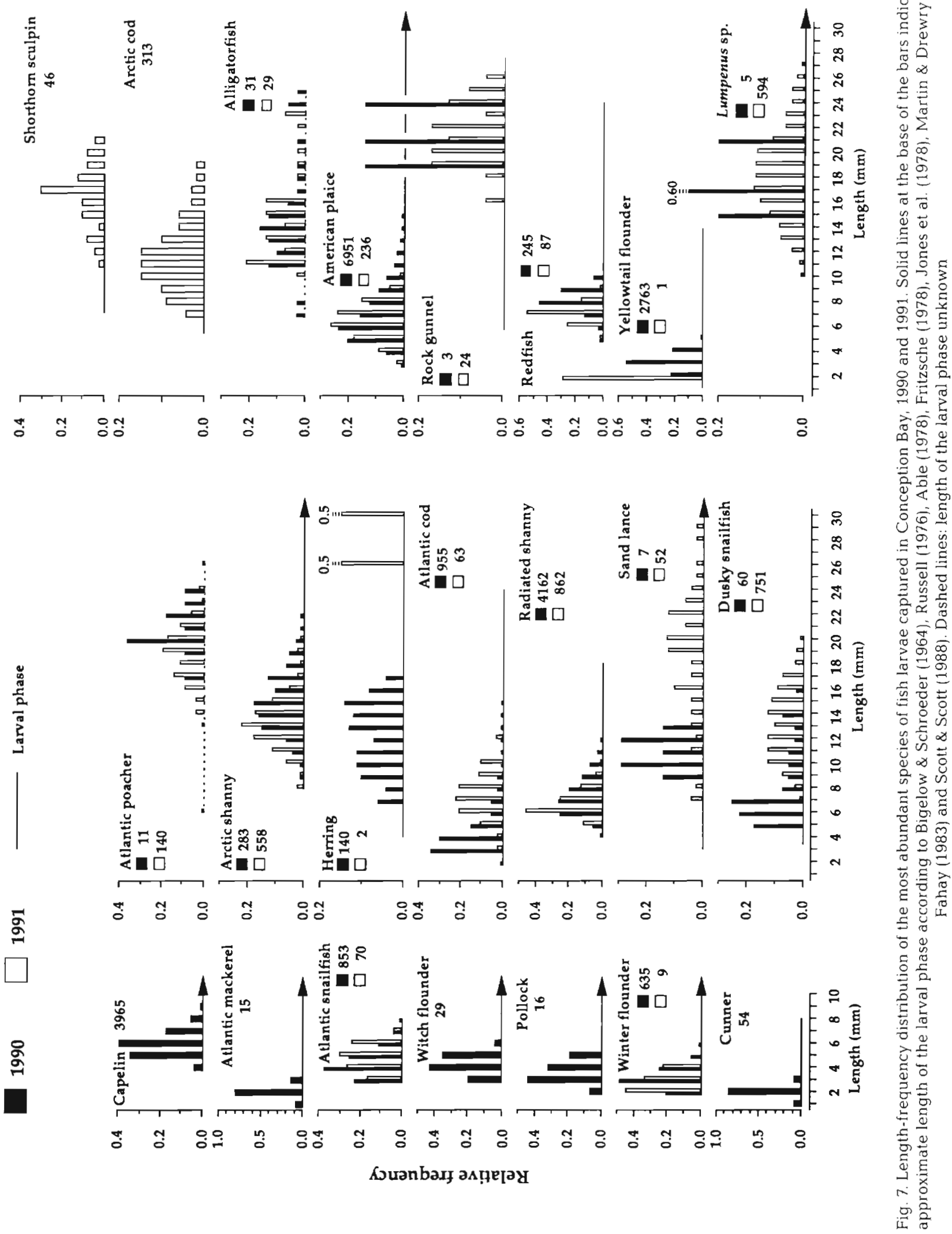


There were significant temporal changes in the abundance of fish larvae in both years. In 1990, the average abundance initially decreased from 185 larvae per $1000 \mathrm{~m}^{3}$ on June $28-29$ to 89 larvae per $1000 \mathrm{~m}^{3}$ on July $3-4$, and then steadily increased as the season progressed to reach 418 larvae per $1000 \mathrm{~m}^{3}$ on July $15-16$. Most of the initial reduction in the total number of larvae was due to plaice (Fig. 8). Abundances of redfish and Arctic shanny also decreased significantly as the season progressed. Most of the increase in larval abundances in the second part of the cruise was due to capelin, which went from less than 1 larvae per $1000 \mathrm{~m}^{3}$ in June 28-29 to 266 larvae per $1000 \mathrm{~m}^{3}$ on July $15-16$. The abundances of yellowtail, snailfishes, winter and radiated shanny also increased as the season progressed. Cod abundances varied in the same fashion as total abundances whereas herring abundances peaked in the second and the last sampling periods.

In 1991, the abundance of fish larvae diso increased as the season progressed. The average abundance of larvae doubled after the first week of sampling, going from 18 larvae per $1000 \mathrm{~m}^{3}$ on July 3 to 35 larvae $1000 \mathrm{~m}^{3}$ on July 9 , and romained stable until July 15. However, winter flounder and shorthorn sculpin were the only species for which temporal variations in abundance were statistically significant (Fig. 8). Both were more abundant at the end of the sampling period.

Temporal changes in the size of fish larvae were also found for some species. In 1990, herring, plaice, yellowtail, capelin and shannies became larger as the season progressed (Fig. 9). In 1991, larvae of all species captured in significant number were larger at the end of the sampling period. The average size of radiated shannies and plaice at the end of 1991 were similar to those of these species at the beginning of 1990 .

Spatial distribution of fish larvae in 1990 and 1991 resembled that of eggs, with highest concentrations generally found at the head of the bay (Fig. 10). However, distribution was sometimes skewed towards the western side of the bay, and patches of high abundances were also observed in the region of the mouth, extending in a SW-NE direction on July $11-13,1990$. There was also species segregation in spatial distribution. For example, in 1991, radiated shanny, dusky snailfish, plaice and alligatorfish were significantly more abundant in the bay than on adjacent shelf waters whereas the reverse was true for redfish, shorthorn sculpin and cod (Mann-Whitney $U$-test, $p<0.05)$. Atlantic snailfish and rock gunnel were absent from samples collected outside the bay. Poacher, Arctic cod, cod, Lumpenus sp. and shannies were on average larger inside the bay whereas dusky snailfish were larger outside the bay (KolmogorovSmirnov test, $\mathrm{p}<0.05$ ).

Total abundance of fish larvae was not significantly associated with temperature or salinity in 1990 (Table 6). In 1991 , only $15 \%$ of the variability was explained by these variables. As in the case of eggs, the highest abundances were associated with the warmest waters that year. The small correlation between total abundance of larvae and environmental conditions in the 2 years may be partly due to pooling species together. In 1990, the 3 most abundant species showed speciesspecific relationships with temperature and salinity. No significant relationships were found in the case of capelin. Cod was found to be associated with the warmest and least saline waters whereas the opposite was true for yellowtail. Overall, the abundance of only 4 of the 12 species present in more than $20 \%$ of the samples in 1990 was significantly associated with temperature and/or salinity. In 1991, 10 of the 14 species collected in more than $20 \%$ of the samples were significantly associated with these variables. The proportion of the variability explained ranged from a low of $10 \%$ (Arctic cod) to a high of $52 \%$ (radiated shanny).

Table 6. Relationships between log-transformed abundances of fish larvae and environmental conditions in Conception Bay, 1990 and 1991 Linear correlation coefficients were partialled for the day of year. Squared multiple correlation coefficients $\left(R^{2}\right)$ are also presented. Only significant $(p<0.05)$ coefficients are shown. The sign of non-significant correlations is also shown

\begin{tabular}{|c|c|c|c|c|c|}
\hline \multirow{2}{*}{$\begin{array}{l}\text { Year } \\
\quad \text { Species }\end{array}$} & \multicolumn{2}{|c|}{ Temperature } & \multicolumn{2}{|c|}{ Salinity } & \multirow[t]{2}{*}{$\mathrm{R}^{2}$} \\
\hline & $5 \mathrm{~m}$ & Avg. $40 \mathrm{~m}$ & $5 \mathrm{~m}$ & Avg. $40 \mathrm{~m}$ & \\
\hline \multicolumn{6}{|l|}{$1990(n=97)$} \\
\hline American plaice & - & 0.42 & - & -0.33 & 0.32 \\
\hline Atlantic cod & + & 0.56 & - & -0.45 & 0.41 \\
\hline Radiated shanny & 0.36 & + & - & - & 0.17 \\
\hline Yellowtail flounder & -0.27 & + & - & - & 0.16 \\
\hline All species & - & + & - & - & + \\
\hline \multicolumn{6}{|l|}{$1991(n=98)$} \\
\hline American plaice & 0.56 & 0.40 & 0.31 & + & 0.35 \\
\hline Arctic cod & - & - & -0.28 & -0.22 & 0.10 \\
\hline Atlantic cod & -0.23 & - & -0.38 & -0.32 & 0.18 \\
\hline Atlantic poacher & -0.24 & - & -0.32 & - . & 0.13 \\
\hline Arctic shanny & - & + & -0.43 & -0.33 & 0.20 \\
\hline Atlantic snailfish & 0.34 & 0.30 & + & + & 0.14 \\
\hline Radiated shanny & 0.70 & 0.47 & 0.34 & + & 0.52 \\
\hline Redfish & -0.24 & -0.34 & -0.36 & - & 0.24 \\
\hline Sand lance & - & - & - & + & 0.12 \\
\hline Shorthorn sculpin & -0.25 & - & - & -0.29 & 0.15 \\
\hline All species & 0.32 & 0.29 & - & - & 0.15 \\
\hline
\end{tabular}



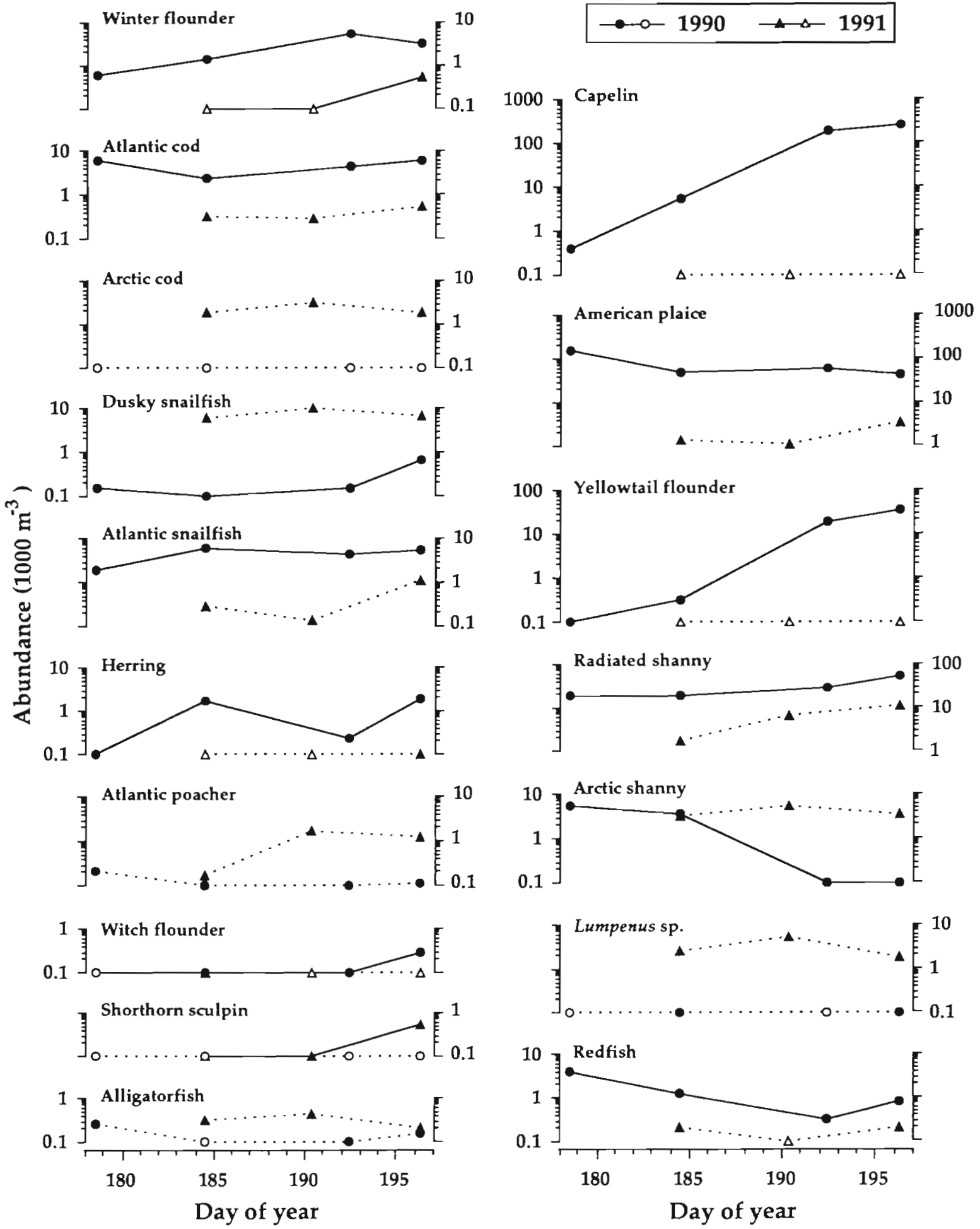

Fig. 8. Seasonal fluctuations in the abundance of the most abundant species of fish larvae captured in Conception Bay, 1990 and 1991. Open symbols indicate absence of the species in the samples. Solid lines indicate significant differences $(p<0.05)$ between 2 adjacent sampling periods (1-way ANOVA and SNK tests on log-transformed data) 

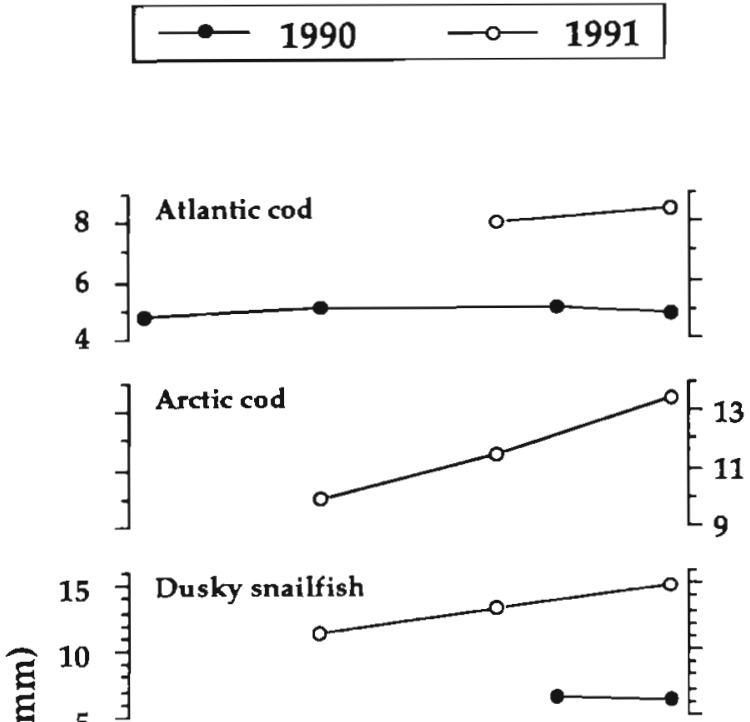

5
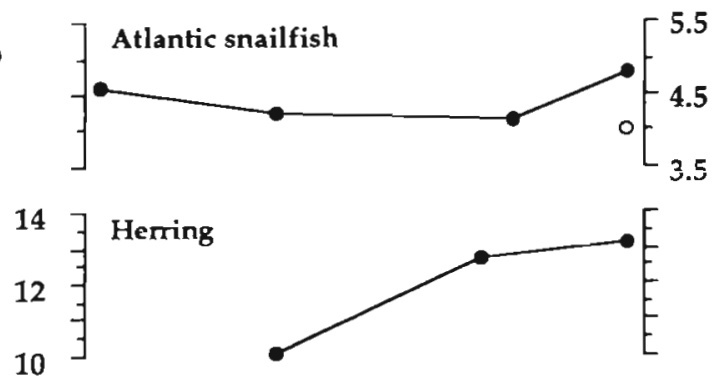

10
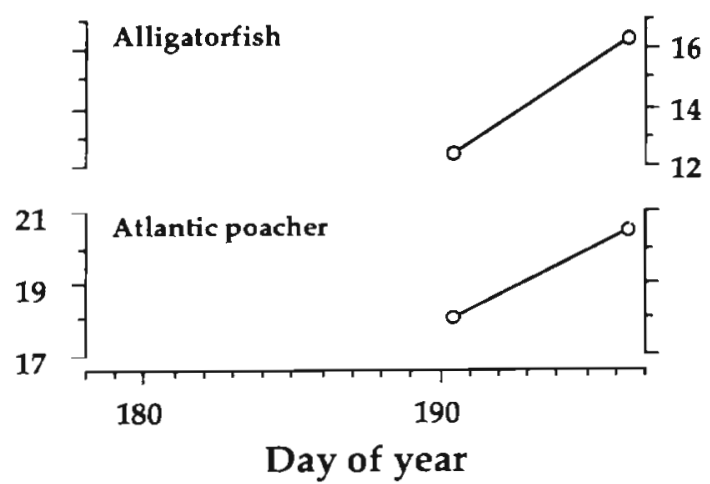
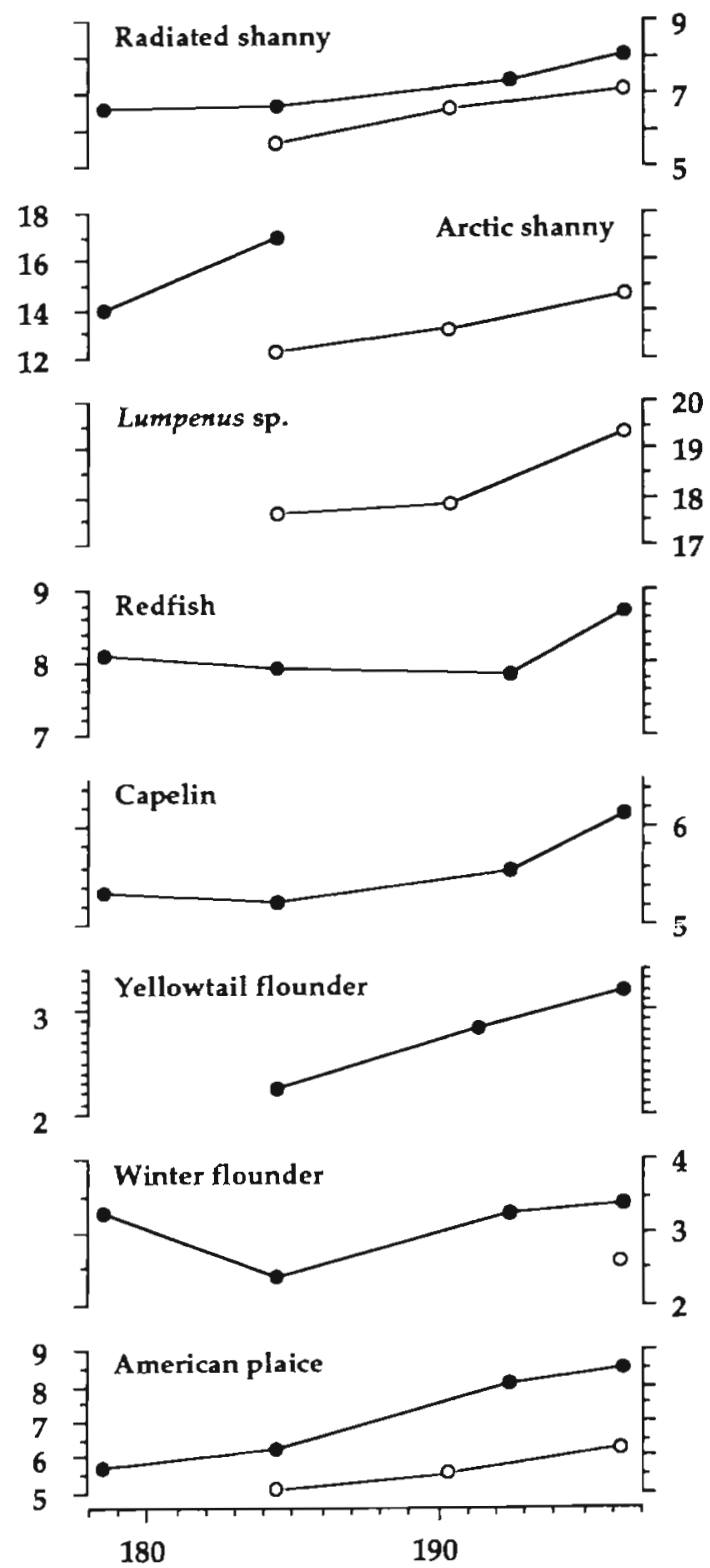

Day of year

Fig. 9. Seasonal fluctuations in the size of the most abundant species of fish larvae captured in Conception Bay, 1990 and 1991. Solid lines indicate significant differences $(p<0.05$ ) between 2 adjacent sampling periods (Kolmogorov-Smirnov tests on frequency distributions)

There were also significant relationships between environmental factors and the size of some species (Table 5). In 1990, largest cod were found in the most saline waters whereas largest capelin and shannies were associated with the warmest and less saline waters. In 1991, largest dusky snailfish were found in the coldest and less saline waters whereas Artic shanny were usually found in the warmest waters.

\section{Larval fish assemblages}

Clustering samples collected in 1990 and 1991 on the basis of their similarity in larval fish relative species composition resulted in 5 groups (Fig. 11). The first 3 principal axes of the principal coordinate analysis explained $66 \%$ of the variability (Table 7 ). The position of the groups on the reduced plane followed a linear gradient from $\mathrm{A}$ to $\mathrm{C}$ which is characteristic of a gradual 

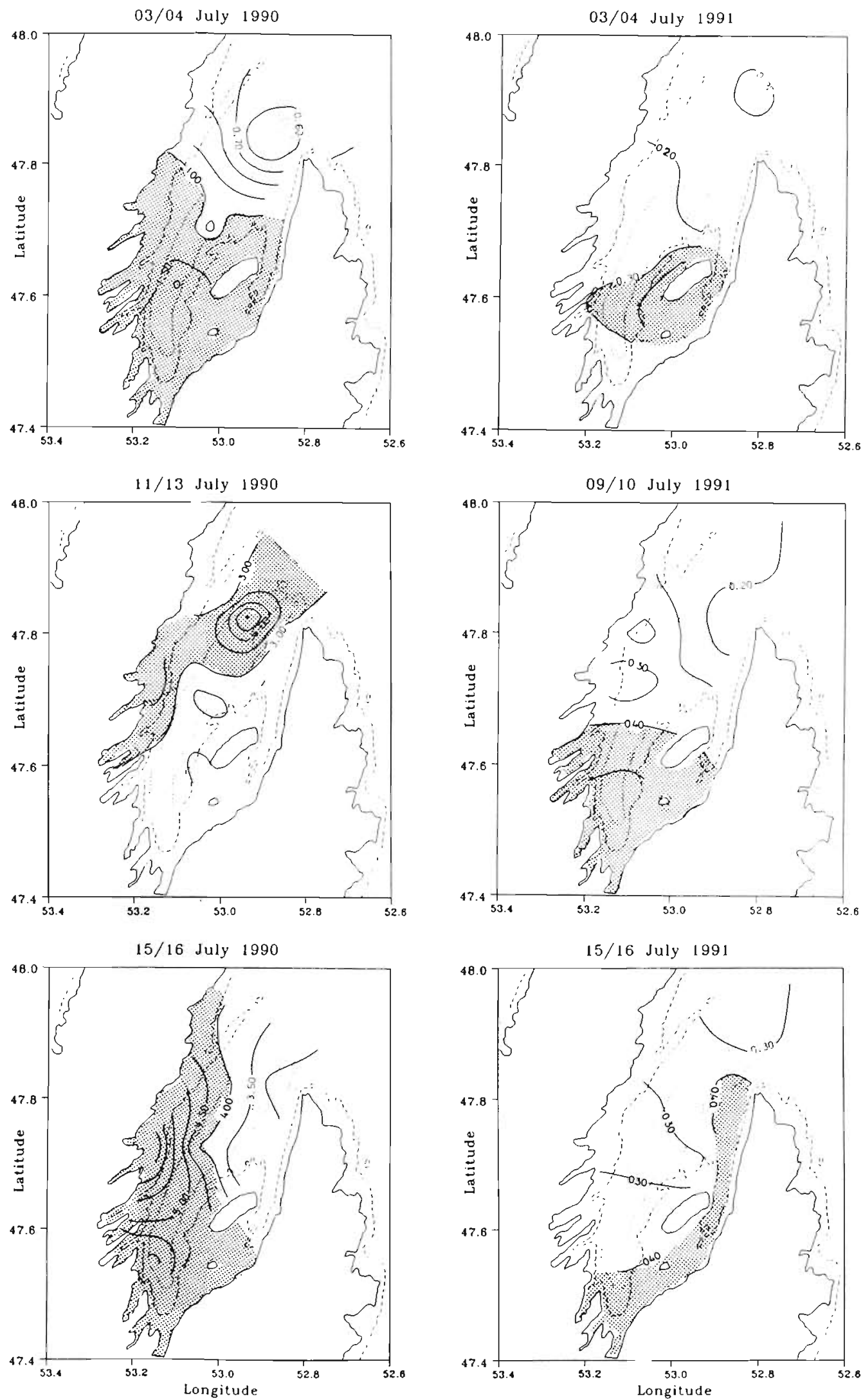

Fig. 10. Spatial distribution of fish larvae in Conception Bay, 1990 and 1991. Abundances in number per $10 \mathrm{~m}^{3}$ Shaded areas indicate regions of higher abundances 


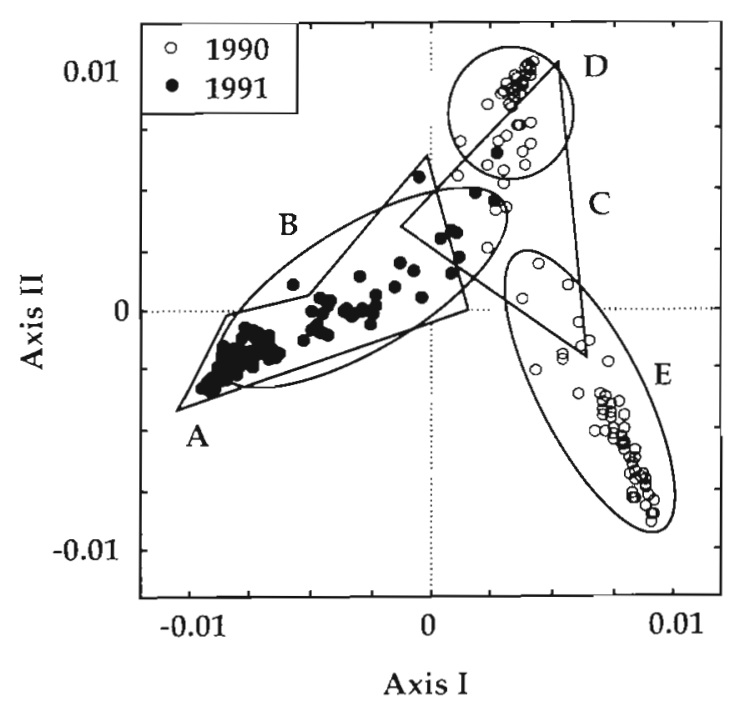

Fig. 11. Fish larvae in Conception Bay, 1990 and 1991: simultaneous projection of samples and groups of samples on the first 2 axes of a principal coordinate analysis. Clustering of samples was obtained using a hierarchical agglomerative clustering model. Groups were formed at the similarity level of 083

succession of species (Fig. 11). However, groups D and $E_{1}$ which appear to stem from group C, were highly segregated. The first axis, negatively correlated with the presence of poacher, Arctic cod, dusky snailfish, Lumpenus sp., redfish and Arctic shanny, and positively correlated with all other species, contributed to separating groups $\mathrm{A}$ and $\mathrm{B}$ from groups $\mathrm{C}, \mathrm{D}$ and $\mathrm{E}$. The second axis, positively correlated with cod, plaice,

Table 7. Fish larvae in Conception Bay, 1990 and 1991. Spearman correlation coefficients between the relative abundance of each species in each sample and the first 3 axes of the principal coordinate analysis. \% of variance: percentage of the variance explained by each axis. Bold coefficients are significant at $p \leq 0.05$

\begin{tabular}{|c|c|c|c|}
\hline $\begin{array}{r}\text { Axis: } \\
\% \text { of variance: }\end{array}$ & $\begin{array}{c}1 \\
33\end{array}$ & $\begin{array}{l}\text { II } \\
21\end{array}$ & $\begin{array}{l}\text { III } \\
12\end{array}$ \\
\hline American plaice & 58 & 57 & 2 \\
\hline Arctic cod & -79 & -9 & 0 \\
\hline Arctic shanny & -72 & 20 & 36 \\
\hline Atlantic poacher & -58 & -11 & 11 \\
\hline Atlantic cod & 26 & 25 & 29 \\
\hline Atlantic herring & 41 & -4 & 1 \\
\hline Atlantic snailfish & 58 & 16 & -19 \\
\hline Capelin & 84 & -51 & 10 \\
\hline Dusky snailfish & -60 & -12 & -43 \\
\hline Lumpenus sp. & -77 & -13 & -26 \\
\hline Radiated shanny & 33 & 18 & -62 \\
\hline Redfish & -22 & 34 & 39 \\
\hline Winter flounder & 74 & -32 & -6 \\
\hline Yellowtail flounder & 77 & -62 & 7 \\
\hline
\end{tabular}

Atlantic snailfish, redfish and shannies, and negatively correlated with capelin, winter and yellowtail flounders, contributed to separating groups C, D and E. Finally, the third axis, positively correlated with cod, redfish and Arctic shanny, and negatively correlated with snailfishes, Lumpenus $\mathrm{sp}$. and radiated shanny, contributed to separating groups $\mathrm{A}$ and $\mathrm{B}$. The clusters mainly reflected differences in species composition between the 2 years. Groups A and B included samples taken in 1991 whereas groups D and E were composed of samples collected in 1990. However, the analysis also revealed overlap between the 2 years: group $C$ was composed of samples coming from both years.

The 2 first functions of the discriminant analysis carried out to separate the groups on the basis of environmental conditions and day of year explained $98 \%$ of the intergroup variance (Wilks' lambda $=0.03$, $p<0.0001)$. The first axis, mainly correlated with salinity and temperature averaged for the first $40 \mathrm{~m}$ of the water column (Table 8), contributed to the separation of all groups. The second axis, mainly correlated with the day of year, separated groups A, B and C. When oniy physical descriptors were used in a ieclassification scheme, $80 \%$ of the samples were reclassified in their original group.

Fig. 12 shows the relative species composition for each group as a function of the physical characteristics of the samples. Samples coming from the coldest and freshest waters of 1991 were dominated by Arctic shanny, Arctic cod, Lumpenus sp. and dusky snailfish, all cold water species (Scott \& Scott 1988). Whereas the importance of these species in the assemblage diminished as salinity and temperature increased, the importance of radiated shanny and plaice increased to dominate the assemblage in group $\mathrm{C}$, which was characteristic of the warmest waters in 1991 and the coldest waters in 1990. As salinity and temperature increased in 1990, the importance of plaice increased accordingly to constitute almost $80 \%$ of all larvae cap-

Table 8. Fish larvae in Conception Bay, 1990 and 1991. Contribution of environmental variables (standardized canonical coefficients) to the formation of the first discriminant axes separating the groups of samples. \% of variance: percentage of the variance explained by each axis. Numbers in parentheses indicate rank in decreasing order of importance

\begin{tabular}{|llcc|}
\hline & Axis: & I & II \\
& \% of variance: & 68 & 29 \\
\hline Day of year & & $0.34(3)$ & $2.09(1)$ \\
Temperature & $5 \mathrm{~m}$ & $-0.20(4)$ & $-0.45(2)$ \\
& Avg. $40 \mathrm{~m}$ & $1.36(2)$ & $-0.13(4)$ \\
Salinity & $5 \mathrm{~m}$ & $-0.09(5)$ & $-0.17(3)$ \\
& Avg. $40 \mathrm{~m}$ & $1.65(1)$ & $0.05(5)$ \\
& & & \\
\hline
\end{tabular}



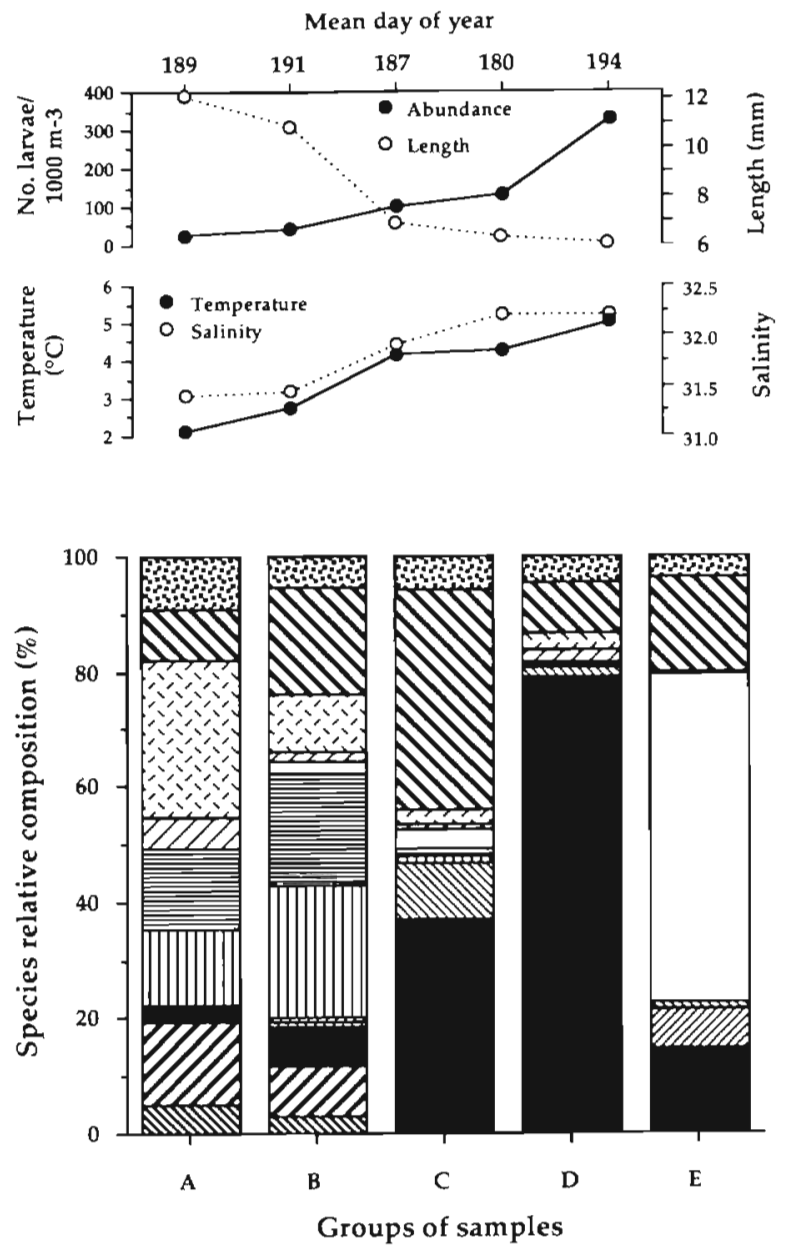

\begin{tabular}{|c|c|c|c|}
\hline 日 Other spp. & $\square$ M. villosus & $\theta$ & P. fermigina \\
\hline $\mathbf{Q}$ U. subbiffurcata & 目 Lumpenus sp. & $\square$ & H. platessoides \\
\hline 曰S.punctatus & 마 L.gibbus & $a$ & B. saida \\
\hline D Sebastes sp. & Q L. atlanticus & $\mathbf{\$}$ & A. decagonus \\
\hline
\end{tabular}

Fig. 12. Conception Bay, 1990 and 1991: species composition, average abundance and size of fish larvae in the groups of samples revealed by the multivariate analyses. Mean temperature, salinity and day of year are also presented for comparison

tured in samples of group D. The warmest and the most saline waters in 1990 were overwhelmingly dominated by capelin.

Other biological characteristics of the groups of samples showed strong associations with environmental conditions (Fig. 12). Total abundance of fish larvae increased exponentially with temperature $\left(R^{2}=0.97\right.$. $p=0.0001)$ and salinity $\left(R^{2}=0.89, p=0.0001\right)$ whereas the average size and the species diversity $H^{\prime}$ of fish larvae decreased as a linear function of temperature $\left(\mathrm{R}^{2}=0.95\right.$ and $\left.0.71, \mathrm{p}=0.0001\right)$ and salinity $\left(\mathrm{R}^{2}=0.95\right.$ and $0.92, p=0.0001$ ). No significant relationships were found between biological characteristics of the groups and the day of year.

\section{DISCUSSION}

In this study, the eggs and larvae of at least 33 species of fish were found in Conception Bay. This represents a significant addition of 13 species to previous ichthyoplankton lists published for the area. Frank \& Leggett (1983) reported 20 species from a small embayment on the northwestern side of the bay, of which 19 were found in our samples. Of the 16 species reported in studies conducted offshore, over the entire northeast Newfoundland/Labrador shelf (Frost 1938, Serebryakov 1965), 10 were found in our samples.

Several species appear to use Conception Bay as a spawning ground. The pelagic eggs of 8 species were collected and their stage of development in 1991 indicates spawning within the bay. Moreover, most of these species were absent from adjacent shelf waters. The presence of newly hatched larvae of benthic, beach and intertidal spawners, which indicates spawning and hatching in the bay, is consistent with previous findings of Frank \& Leggett (1983). Newly released redfish larvae, an ovoviviparous species of fish, were also collected.

Interannual and seasonal differences in both species composition and abundance of ichthyoplankton in the bay appear to be associated with differences in environmental conditions, particularly with temperature. Both egg and larval abundances were lower by an order of magnitude in 1991 corresponding to the coldest and less saline waters. Larval fish composition in 1990 was mainly characterized by warmer water species such as mackerel, whereas boreal species such as Arctic cod were more common in 1991 (Scott \& Scott 1988). The biological development (presence of eggs and larval stages, larval sizej of some species in 1991 was delayed compared to 1990 , most probably due to lower temperature.

Temperature was the single characteristic of the habitat most associated with the spatial distribution of eggs. In both years, highest abundances of all species were usually found at the head of the bay, corresponding to the warmest waters. Moreover, highest abundances were found on the northwest side of the bay on July $11-13,1990$, corresponding to the movement of warmest isotherms to that side of the bay. This strong association between fish eggs and surface temperatures may be explained by 2 factors. First, spawning activity of both demersal and pelagic spawners is usually related to temperature (e.g. Gagné \& O'Boyle 1984, Ellertsen et al. 1989, Borkin 1992, Frank et al. 1992). Therefore, warmer waters found over the extensive shallow areas at the head of the bay may constitute the most suitable spawning habitats for the 2 types of fish. Second, egg distribution is influenced by circulation and most likely has a response to external 
forcing factors similar to that exhibited by surface temperature. Planktonic animals are transported along with water masses which allow them to remain in relatively stable habitats (Laprise \& Dodson 1993, 1994). The relationship observed between wind patterns, temperature and egg distribution in Conception Bay supports this suggestion.

Highest abundances of fish larvae usually occurred at the head of the bay, similar to eggs. However, patches of high abundances were also observed in other areas of the bay and environmental conditions explained only a small part of the variability in larval fish distribution patterns. As many species were common only in 1 of the 2 years, we could not isolate effects of temperature and salinity as in the case of eggs. Radiated shanny and plaice were the only species clearly associated with the warmest waters in both years. Other species were either associated with warm or cold waters, high or low salinities, bay or shelf waters, indicating spatial segregation among species. Nonlinear relationships with environmental conditions, small-scale patchy distribution and other factors not measured in this study (e.g. transport) may expiain the weak relationships observed.

Clustering samples by their relative species composition revealed well-defined assemblages of fish larvae, and the variability in relative species composition was strongly associated with the physico-chemical conditions of the surface layer. Despite the short period of time covered by our surveys, changes in species composition following increasing temperature and salinity resembled patterns of seasonal successions reported for an adjacent ecosystem (Gulf of St. Lawrence; de Lafontaine et al. 1991). However, in contrast to that study, changes in species composition were not related to the day of year. Coldest and freshest waters in 1991 were dominated by cold water species such as Arctic shanny, Arctic cod and Lumpenus sp. Radiated shanny and plaice larvae were characteristic of the warmest waters in 1991 and the coldest waters in 1990. Capelin was characteristic of samples collected in the warmest waters in 1990 .

Other biological characteristics of species assemblages were also strongly associated with temperature and salinity, but not with the day of year. Concomitant decrease in larval size and increase in larval abundance for species hatched within the bay suggests that the system changes from being mainly dominated by larvae and juveniles produced outside the bay to being highly dominated by species produced inside the bay. Changes in species diversity support this suggestion. Diversity decreased in warmer waters to reach values similar to those observed in semi-enclosed and estuarine environments, where few species overwhelmingly dominate larval fish assemblages (de Lafontaine et al.
1990). The synchronous emergence of the huge quantity of larvae of species laying benthic eggs on the beach (capelin) and shallow intertidal waters (radiated shanny, seasnails, winter flounder) is clearly one of the major factors affecting characteristics of ichthyoplankton in Conception Bay. Temperature is considered as the principal cue synchronizing emergence of these larvae (Frank \& Leggett 1983).

These results suggest that temperature is the principal factor controlling spatio-temporal occurrence of fish eggs and larvae in Conception Bay and, most probably, in coastal waters of Newfoundland and Labrador. Temperature is a primary factor associated with the occurrence and distribution of young stages of fish inhabiting temperate and cold oceans (e.g. Ellertsen et al. 1981, Obenchain 1981, Doyle \& Ryan 1989, Frank et al. 1992). This association may be critical in ecosystems characterized by an extremely short growing season (Conover 1992). Higher temperatures increase the metabolism of fish larvae (see review of Blaxter 1992), therefore decreasing egg development time and enhancing larval growth (Pepin 1991). In addition, greater larval foud proúciuon aind abundance may be associated with warmer waters, which further enhances growth rates of larvae (Frank \& Leggett 1982, Taggart \& Leggett 1987). Finally, invertebrate predators may be less abundant in warmer surface waters, increasing survival through the larval phase (Frank \& Leggett 1982, 1983, Taggart \& Leggett 1987). The synchronous emergence of several species of fish larvae in the planktonic environment driven by temperature may be a strategy to further reduce predation (Frank \& Leggett 1983). The association observed between salinity and ichthyoplankton in this study is probably artifactual. While influences of temperature and salinity could not be always separated, it is unlikely that the small differences in salinity observed between samples would greatly affect marine animals. Although wind influenced the spatial distribution of eggs in the bay, this factor had little effect on the relationship between their abundance and temperature. The location of the most favourable habitats in Conception Bay (presumably warmest water masses) is variable at the scale of the bay and partly depends on wind patterns. As eggs drift along with water masses, this allow them to remain in the most favourable conditions for the longest period of time.

Conception Bay may play an important role in the early-life history of fish inhabiting northeast Newfoundland/Labrador shelves. As inshore, surface waters usually warm earlier in spring and reach higher temperatures in summer than offshore waters due to the presence of extensive shallow areas, bays and coastal waters offer favourable habitats for the ichthyoplankton. Even if a smaller proportion of fish reproduced in 
the coastal region, their offspring may contribute significantly to the number of individuals recruiting to the population if growth and survival are considerably higher in coastal areas than in offshore areas. Differential survival of eggs and larvae could explain the observation that juveniles of many commercial species of the ecosystem are found in larger numbers in coastal waters. Strategies such as spawning in the bay may allow species to take advantage of favourable physical and biological conditions. At the minimum surface temperature recorded $\left(3^{\circ} \mathrm{C}\right)$, the average incubation time for a fish egg is $13.6 \mathrm{~d}$ (Pepin 1991), which is shorter than the estimated physical retention time in the bay. Retention time, which is defined as the period necessary for $50 \%$ of the population to be lost from the bay due to transport, may be as long as $30 \mathrm{~d}$ in Conception Bay (de Young et al. 1994). Moreover, hatching would occur within $9 \mathrm{~d}$ at temperatures varying between 7 and $9^{\circ} \mathrm{C}$, the average temperature for 1991 and 1990, respectively. Larvae hatched from benthic eggs laid in the bay like winter flounder or having short planktonic larval stages such as yellowtail flounder may also have sufficient time to complete their development inside the bay. For other species, any strategy allowing larvae to spend some time in coastal waters could increase growth and survival.

Acknowledgements. The participation of the captains and crews of CSS 'Marinus' and CSS 'Shamook' is gratefully acknowledged. Valuable technical assistance was provided by C. Bydek, C. Kean, G. Sheppard and P. Stead. We especially thank S. Campbell, E. Colbourne, J. Helbig and T. Shears for their help during the entire project. R.L. was supported by a visiting fellowship from the Department of Fisheries and Oceans

\section{LITERATURE CITED}

Able KW (1978) Ichthyoplankton of the St. Lawrence Estuary: composition, distribution and abundance. J Fish Res Bd Can 35:1518-1531

Bigelow HB, Schroeder WC (1964) Fishes of the Gulf of Maine. Fish Bull US Fish Wild Serv 74:1-577

Blaxter JHS (1992) The effect of temperature on larval fishes. Neth J Zool 42:336-357

Boehlert GW, Mundy BC (1993) Ichthyoplankton assemblages at seamounts and oceanic islands. Bull mar Sci 53: $336-362$

Borkin IV (1992) Ichthyoplankton of the coastal waters of Western Spitsbergen. J Ichthyol 32:145-153

Conover DO (1992) Seasonality and the scheduling of life history at different latitudes. J Fish Biol 41 (Suppl B):161-178

Cushing DH (1975) Marine ecology and fisheries. Cambridge University Press, Cambridge

de Lafontaine Y (1990) Ichthyoplankton communities in the St. Lawrence Estuary: composition and dynamics. In: ElSabh MI, Silverberg N (eds) Oceanography of a largescale estuarine system: the St. Lawrence. Springer-Verlag, New York, p 321-343 de Lafontaine Y, Demers S, Runge J (1991) Pelagic food web interactions and productivity in the Gulf of St. Lawrence: a perspective. In: Theriault JC (ed) The Gulf of St. Lawrence: small ocean or big estuary? Can Spec Publ Fish Aquat Sci 113:99-123

de Young B, Anderson JT, Greatbach RJ, Fardy P (1994) Advection diffusion modelling of larval capelin (Mallotus villosus) dispersion, in Conception Bay, Newfoundland. Can J Fish Aquat Sci 51:1297-1307

Doyle MJ, Morse WW, Kendall AW (1993) A comparison of larval fish assemblages in the temperate zone of the northeast Pacific and worthwest Atlantic Oceans. Bull mar Sci 53:588-644

Doyle MJ, Ryan RM (1989) Spatial patterns in a coastal ichthyoplankton community southwest of Ireland. Rapp P-v Réun Cons int Explor Mer 191:70-84

Ellertsen B, Fossum P, Solemdal P, Sundby S (1989) Relation between temperature and survival of eggs and first feeding larvae of northeast Arctic cod (Gadus morhua L.). Rapp P-v Réun Cons int Explor Mer 191:209-219

Ellertsen B, Solemdal P, Stromme T, Sundby S, Tilseth S, Westgård T (1981) Spawning, transport and dispersal of eggs from the spawning area of Arcto-Norwegian cod (Gadus morhua L.). Rapp P-v Réun Cons int Explor Mer 178:260-267

Fahay MP (1983) Guide to the early stages of marine fishes occuring in the western North Atlantic Ocean, Cape Hatteras to the southern Scotian Shelf. J Northw Atlant Fish Sci 4:1-423

Frank KT, Leggett WC (1981) Wind regulation of emergence times and early larval survival in capelin (Mallotus villosus). Can J Fish Aquat Sci 38:215-223

Frank KT, Leggett WC (1982) Coastal water mass replacement: its effect on zooplankton dynamics and the predator-prey complex associated with larval capelin (Mallotus villosus). Can J Fish Aquat Sci 39:991-1003

Frank KT, Leggett WC (1983) Multispecies larval fish associations: accident or adaptation? Can $J$ Fish Aquat Sci 40:754-762

Frank KT, Loder JW, Carscadden JE, Leggett WC, Taggart CT (1992) Larval flatfish distributions and drift on the Southern Grand Bank. Can J Fish Aquat Sci 49:467-483

Fritzsche RA (1978) Development of fishes of the mid-Atlantic Bight: an atlas of egg, larval and juvenile stages, Vol 5, Chaetodontidae through Ophididae. Fish and Wildlife Service, Washington, DC

Fromentin JM, Ibanez F, Legendre P (1993) A phytosociological method for interpreting plankton data. Mar Ecol Prog Ser 93:285-306

Frost N (1938) Some fishes of Newfoundland waters. Newfoundland Dept Nat Resour Res Bull 4:1-16

Gagné JA, O'Boyle RN (1984) The timing of cod spawning on the Scotian Shelf. In: Dahl E, Danielssen DS, Moksness E, Solemdal P (eds) The propagation of cod Gadus morhua L. Flødevigen rapportser 1:501-517

Harden Jones FR (1969) Fish migration. Edward Arnold, London

Jones PW, Martin FD. Hardy JD (1978) Development of fishes of the mid-Atlantic Bight: an atlas of egg, larval and juvenile stages, Vol 1, Acipenseridae through Ictaluridae. Fish and Wildlife Service, Washington, DC

Keats DW (1990) A nocturnal inshore movement of juvenile cod Gadus morhua L. in eastern Newfoundland. J exp mar Biol Ecol 139:167-173

Lance GN, Williams WT (1967) A general theory of classificatory sorting strategies. I. Hierarchical systems. Computer J 9:373-380 
Laprise R, Dodson JJ (1993) Nature of environmental variability experienced by benthic and pelagic animals in the St. Lawrence Estuary, Canada. Mar Ecol Prog Ser 94: $129-139$

Laprise R, Dodson JJ (1994) Environmental variability as a factor controlling spatial patterns in distribution and species diversity of zooplankton in the St. Lawrence Estuary. Mar Ecol Prog Ser 107:67-81

Leis JM (1993) Larval fish assemblages near Indo-Pacific coral reefs. Bull mar Sci 53:362-392

Legendre L, Legendre P (1984) Ecologie numérique, Vol II, La structure des données écologiques, 2nd edn. Masson and Presses de l'Université du Québec, Québec

Legendre P, Vaudor A (1991) Le Progiciel R - analyse multidimensionnelle, analyse spatiale. Université de Montréal, Montréal

Leggett WC (1985) The role of migrations in the life history evolution of fish. Contrib mar Sci 27:277-295

Loeb VJ, Smith PE, Moser HG (1983a) Geographical and seasonal patterns of larval fish species structure in the California Current area, 1975. Calif coop ocean Fish Inv Rep $24: 132-151$

Loeb VJ, Smith PE, Moser HG (1983b) Recurrent groups of larval fish species in the California Current area. Calif coop ocean Fish Inv Rep 24:152-164

Markle DF, Frost LA (1985) Comparative morphology, seasonality, and a key to planktonic fish eggs from the Nova Scotian Shelf. Can J Zool 63:246-257

Martin FD, Drewry GE (1978) Development of fishes of the mid-Atiantic Bight: an atlas of egg, larval and juvenile stages, Vol 6, Stromateidae through Ogcocephalidae. Fish and Wildlife Service, Washington, DC

This article was submitted to the editor
McGowen GE (1993) Coastal ichthyoplankton assemblages, with emphasis on the southern California Bight. Bull mar Sci 53:692-722

Obenchain CL (1981) A study of the larval fish community in the New York Bight, July 1974 to June 1976. Rapp P-v Réun Cons int Explor Mer 178:217-219

Page FH, Frank KT (1989) Spawning time and egg stage duration in Northwest Atlantic haddock (Melanogrammus aeglefinus) stocks with emphasis on Georges and Brown Banks. Can J Fish Aquat Sci 46 (Suppl 1):68-81

Pepin P (1991) Effect of temperature and size on development, mortality and survival rates of the pelagic early life history stages of marine fish. Can $J$ Fish Aquat Sci 48:503-518

Russell RRS (1976) The eggs and planktonic stages of British marine fishes. Academic Press, London.

Scott WB, Scott MG (1988) Atlantic fishes of Canada. Can Bull Fish Aquat Sci 219:1-731

Serebryakov VP (1965) Some results of Soviet research work on ichthyoplankton in the Northwest Atlantic: eggs and larvae of cod. ICNAF Spec Publ 6:425-433

Sinclair M (1988) Marine populations: an essay on population regulation and speciation. University of Washington Press, Seattle

Taggart CT, Leggett WC (1987) Short-term mortality in postemergent larval capelin Mallotus villosus. II. Importance of food and predator density, and density-dependence Mar Ecol Prog Ser 41:219-22y

Van Guelpen L, Markle DF, Duggan DJ (1982) An evaluation of accuracy, precision and speed of several zooplankton subsampling techniques. J Cons int Explor Mer 40: $226-236$

Manuscript first received: July 17, 1994

Revised version accepted: January 20, 1995 